\title{
Mechanisms producing different precipitation patterns over north-eastern Italy: insights from HyMeX-SOP1 and previous events
}

Article

Accepted Version

Davolio, S., Volonté, A., Manzato, A., Pucillo, A., Cicogna, A. and Ferrario, M.E. (2016) Mechanisms producing different precipitation patterns over north-eastern Italy: insights from HyMeX-SOP1 and previous events. Quarterly Journal of the Royal Meteorological Society, 142 (S1). pp. 188-205. ISSN 1477-870X doi: https://doi.org/10.1002/qj.2731 Available at https://centaur.reading.ac.uk/88726/

It is advisable to refer to the publisher's version if you intend to cite from the work. See Guidance on citing.

To link to this article DOI: http://dx.doi.org/10.1002/qj.2731

Publisher: Royal Meteorological Society

All outputs in CentAUR are protected by Intellectual Property Rights law, including copyright law. Copyright and IPR is retained by the creators or other copyright holders. Terms and conditions for use of this material are defined in the End User Agreement. 


\section{www.reading.ac.uk/centaur}

\section{CentAUR}

Central Archive at the University of Reading

Reading's research outputs online 


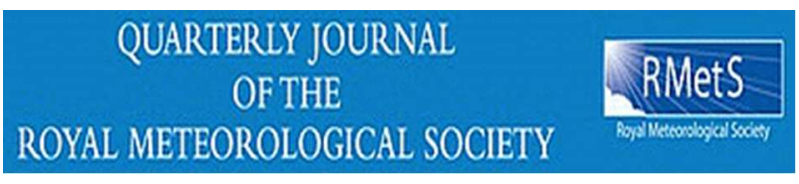

\section{Mechanisms producing different precipitation patterns over North-Eastern Italy: insights from HyMeX-SOP1 and previous events}

\begin{tabular}{|r|l|}
\hline Journal: & QJRMS \\
\hline Manuscript ID & QJ-15-0126.R2 \\
\hline Wiley - Manuscript type: & HyMeX Special Issue \\
\hline Date Submitted by the Author: & n/a \\
\hline Complete List of Authors: & $\begin{array}{l}\text { Davolio, Silvio; Institue of Atmospheric Sciences and Climate (ISAC), } \\
\text { National Research Council of Italy (CNR) } \\
\text { Volontè, Ambrogio; University of Reading, Department of Meteorology } \\
\text { Manzato, Agostino; ARPA FVG - OSMER, } \\
\text { Pucillo, Arturo; ARPA FVG - OSMER, } \\
\text { Cicogna, Andrea; ARPA FVG - OSMER, } \\
\text { Ferrario, Massimo; ARPA Veneto, }\end{array}$ \\
\hline Keywords: & heavy precipitation, orography, convection, HyMeX, Alps \\
\hline
\end{tabular}


1 Mechanisms producing different precipitation patterns over North-Eastern Italy: insights

\section{2 from HyMeX-SOP1 and previous events}

3

4

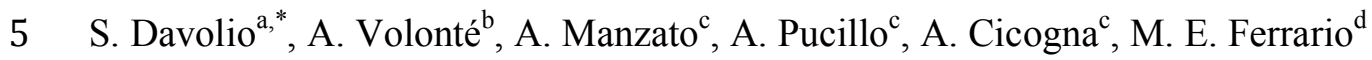

6

7

8

9 a Institute of Atmospheric Sciences and Climate (ISAC), National Research Council of Italy (CNR),

10 Bologna, Italy

$11{ }^{b}$ Department of Meteorology, University of Reading, UK - formerly Dep. of Physics, University of 12 Milan, Italy

$13{ }^{\mathrm{c}}$ ARPA Friuli Venezia Giulia - OSMER, Visco (Udine), Italy $\square$

$14 \quad$ d ARPA Veneto, Servizio Meteorologico, Teolo (Padua), Italy $\square$

15

$16{ }^{*}$ Correspondence to: S. Davolio, Institute of Atmospheric Sciences and Climate (ISAC), National 17 Research Council of Italy (CNR), Via Gobetti 101, Bologna 40129, Italy.

18 E-mail: S.Davolio@isac.cnr.it

19

20 Key words: heavy precipitation, orography, HyMeX, Alps, convection

21 
ABSTRACT

During the first HyMeX Special Observation Period (SOP1) field campaign, the target site of North Eastern Italy (NEI) experienced a large amount of precipitation, locally exceeding the climatological values and distributed among several heavy rainfall episodes. In particular, two events that occurred during the last period of the campaign drew our attention. These events had common large-scale patterns and a similar mesoscale setting, characterised by southerly low-level flow interacting with the Alpine orography, but the precipitation distribution was very different. During IOP18 (31 October - 1 November 2012), convective systems were responsible for intense rainfall mainly located over a flat area of the eastern Po Valley, well upstream of the orography. Conversely, during IOP19 (4 - 5 November 2012), heavy precipitation affected only the Alpine area. In addition to IOP18 and IOP19, the present study analyses other heavy-precipitation episodes that display similar characteristics and which occurred over NEI during the autumn of recent years. A high-resolution (2-km grid spacing) non-hydrostatic NWP model and available observations are used for this purpose.

The two different observed precipitation patterns are explained in terms of interaction between the impinging flow and the Alps. Depending on the thermodynamic profile, convection can be triggered when the impinging flow is forced to rise over a pre-existing cold-air layer at the base of the orography. In this situation persisting blocked-flow condition and upstream convergence are responsible for heavy rain localized over the plain. Conversely, if convection does not develop, flow-over conditions establish and heavy rain affects the Alps. Numerical parameters proposed in the literature are used to support the analysis.

Finally, the role of evaporative cooling beneath the convective systems is evaluated. It turns out that the stationarity of the systems upstream of the Alps is mainly attributable to persisting blocked-flow conditions, while convective outflow slightly modifies the location of precipitation. 
48

49

50

51

52

53

54

55

56

57

58

59

60

61

62

63

64

65

66

67

68

69

70

71

72

73

\section{Introduction}

During autumn 2012, the first field campaign (Special Observation Period - SOP1, Ducrocq et al., 2014) of the international project HyMeX (Hydrological Cycle in the Mediterranean Experiment; Drobinski et al., 2014) took place with the aim of studying heavy precipitation and floods in the Mediterranean basin. The North Eastern Italy hydro-meteorological site (NEI - Figure 1) was selected from the various target areas over the Italian territory monitored during the campaign, in order to specifically investigate Alpine intense rainfall. NEI has the maximum annual-average precipitation over Italy (Frei and Schär, 1998; Isotta et al., 2013) and was also a target site in previous field campaigns (e.g. Mesoscale Alpine Programme, MAP, Bougeault et al. 2001) and projects (e.g. MAP Demonstration Phase - DPHASE, Rotach et al., 2009). Thus, SOP1 represented a sort of continuation of previous experiments, focusing mainly on the finer scales of atmospheric convection.

During autumn, the deepening of Atlantic troughs over the Mediterranean basin and the relatively high sea surface temperature combine to create atmospheric conditions conducive to heavy rainfall (Doswell et al. 1998; Massacand et al., 1998; Buzzi and Foschini, 2000; Borga et al., 2007; Manzato et al., 2015). The steep and complex orography of the Alpine area makes floods a common hazard during autumn. Autumn 2012 was no exception in this regard: several intense precipitation episodes affected NEI, which turned out to be the rainiest area of the campaign (Davolio et al., 2015). More than $1000 \mathrm{~mm}$ of rainfall was recorded over the Alps of the Friuli Venezia Giulia (FVG) region (see Figure 1 for the location) during the two-month period of SOP1, locally exceeding climatological values for this time of year. Two contrasting, heavy-precipitation events, thoroughly monitored during Intense Observing Periods (IOPs) 18 and 19, particularly drew our attention and prompted this study.

These two IOPs were very close in time and characterised by similar synoptic conditions and intense low-level south-easterly flow over the Adriatic Sea (typically referred to as Sirocco wind) impinging on the Alps. However, they produced quite different precipitation patterns. In IOP18 (31 
74 October - 1 November) the development of convective systems was responsible for intense rainfall 75 confined over a flat area of the eastern Po Valley, far upstream of the orography and close to the 76 Adriatic coast. In contrast, during IOP 19 (4 - 5 November) heavy precipitation affected the 77 mountainous Alpine area and only very light rainfall was recorded over the plain.

78 Different precipitation patterns associated with similar large-scale circulation were already 79 identified and discussed for the north-western Alps in several studies, fostered by MAP. In 80 particular, the characteristics of two episodes of the MAP field campaign (MAP-IOP2b and MAP81 IOP8) were analysed from different perspectives (Rotunno and Ferretti, 2003; Bousquet and Smull, 82 2003; Rotunno and Houze, 2007). It turned out that the different thermodynamic profile of the 83 impinging flow, and thus its different stability, allowed - or prevented - the low-level air from rising 84 over the Alpine barrier. The different orographic flow regime - flow over or flow around (Smith, 85 1979) - determined the location, intensity and characteristics of the precipitation. During MAP86 IOP2b heavy orographic rainfall with embedded convection affected the Alpine slopes, while 87 during MAP-IOP8 weak stratiform and long-lasting precipitation was widespread over the Po 88 Valley.

89 More recently, Barbi et al. (2012) provided a detailed description of four convective episodes 90 affecting the coastal area of the Veneto region (part of NEI, Figure 1) far from the Alpine 91 orography. These events occurred in September of four consecutive years and the associated large 92 rainfall totals represented a peculiar feature in the climatology of the region, which is characterised 93 by maximum annual values over the Alps and lower annual values, but with high occurrence of 94 heavy rainfall, over the plain. In accordance with the finding of Monai et al. (2006) and Davolio et 95 al. (2009b), the authors highlighted the importance of the orographic flow modification: the south96 easterly low-level flow from the Adriatic Sea was blocked and deflected ahead of the Alps, 97 resulting in a north-easterly barrier wind over the plain (Schwerdtfeger, 1984; Di Muzio, 2014). 98 This barrier wind converged with the impinging south-easterly flow near the coastal area and this 
99 low-level convergence, together with conditionally instability, was responsible for initiating and 100 sustaining organised convection.

101 Conversely, in the NEI Pre-Alpine and Alpine area, higher values of annual accumulated 102 precipitation are closely linked to direct orographic uplift of the southerly moisture-laden airflow 103 from the Adriatic Sea, responsible for long-lasting orographic precipitation. Recent flooding 104 episodes over NEI, also mentioned briefly in Barbi et al. (2012), fit within this category of events, 105 which includes typical autumnal heavy rainfall affecting the southern side of the Alps.

106 In the present study, attention is focussed on the period between September and November, when 107 the climatological peak of heavy precipitation is in the north-western Mediterranean (Ducrocq et al., 108 2014), and specifically over NEI (Manzato, 2015). This peak is caused by the higher frequency of 109 Atlantic storms entering the Mediterranean and aided by additional heat and moisture provided by 110 the relatively warm Adriatic Sea. Over NEI, during this period there is a progressive transition from 111 summer convective weather, associated with conditionally unstable flow, to the so-called flux 112 precipitation (Manzato, 2007) typical of long-lasting, sometimes flood-producing, events along the 113 southern side of the Alps and associated with near-neutral moist stratification (Miglietta and 114 Rotunno, 2005; Malguzzi et al., 2006).

115 In addition to IOP18 and IOP19 of the HyMeX-SOP1 mentioned above, other heavy-precipitation 116 episodes displaying similar precipitation patterns and affecting NEI are selected and analysed in this 117 study. The aim is to investigate and better understand possible common thermodynamic 118 mechanisms that modulate the precipitation pattern for the two categories of analysed events and to 119 define analytical parameters able to describe the physical processes associated with the two 120 observed orographic flow regimes.

121 The paper is organised as follows. After a description of the employed numerical models and of the 122 simulation strategy (Section 2), the results of a detailed investigation of the events, based on both 123 observations and high-resolution model simulations, are summarised in Section 3. Section 4 
124 presents the main findings concerning physical mechanisms playing a key role in different phases 125 of the events. Finally, conclusions are drawn in Section 5.

126

127 2. Model description

128 The Numerical Weather Prediction (NWP) system employed in the present study is based on the 129 hydrostatic BOlogna Limited Area Model (BOLAM) and the non-hydrostatic MOdello LOCale in 130 Hybrid coordinates (MOLOCH), developed by the Institute of Atmospheric Sciences and Climate 131 of the Italian National Research Council (CNR - ISAC). The two models are being used 132 operationally at ISAC as part of an agreement with the National Civil Protection Department and 133 also at various Italian national agencies and regional meteorological services. BOLAM and 134 MOLOCH differ in their dynamical core, including a different choice for their vertical coordinate 135 sets, and by the fact that BOLAM includes a parameterization for deep convection, based on a 136 modified version of the Kain-Fritsch scheme (Kain, 2004). In MOLOCH deep convection is 137 explicitly simulated and a simple shallow convection scheme is applied. BOLAM (horizontal 138 resolution $11 \mathrm{~km}, 50$ vertical levels) is run over a European domain and it is mainly employed to 139 provide lateral boundary conditions for the inner grid (horizontal resolution $2.3 \mathrm{~km}$ and 54 vertical 140 levels) of MOLOCH (Figure 1) at 1-hour intervals. This intermediate nesting step has proved to be 141 reliable and economical in bridging the gap between the coarse-resolution global model fields $142\left(0.25^{\circ}\right.$ 6-hourly ECMWF analysis data) and the high-resolution forecasts (Buzzi et al., 2014). 143 Therefore only a brief description of the MOLOCH model is provided here. For a description of 144 BOLAM refer to Buzzi et al. (2003), Malguzzi et al. (2006) and Davolio et al. (2013).

145 MOLOCH is a non-hydrostatic, fully compressible, convection-permitting model (Malguzzi et al., 146 2006; Buzzi et al., 2014). It integrates the set of atmospheric equations with 12 prognostic variables 147 - pressure, absolute temperature, specific humidity, horizontal and vertical components of 148 velocity, turbulent kinetic energy and five water species (cloud water, cloud ice, rain, graupel and 149 snow) - represented on the latitude-longitude, rotated Arakawa C-grid. It employs a hybrid 
150 terrain-following vertical coordinate, depending on air density and smoothing to horizontal surfaces

151 at higher altitudes. Time integration is based on an implicit scheme for the vertical propagation of

152 sound waves, while explicit time-splitting schemes are implemented for integration of the

153 remaining terms of the equations of motion. Three-dimensional advection is computed using the

154 Eulerian weighted average flux scheme (Billet and Toro, 1997). The physical parameterisation

155 schemes are common between the two models. The microphysical scheme is based on the 156 parameterisation proposed by Drofa and Malguzzi (2004). Atmospheric radiation is computed with 157 a combined application of the Ritter and Geleyn (1992) scheme and the ECMWF scheme 158 (Morcrette et al., 2008). The turbulence scheme is based on a turbulent kinetic energy - mixing 159 length $(E-l)$ order 1.5 closure theory (Zampieri et al., 2005). The soil model uses seven layers and it 160 takes into account the observed geographical distribution of different soil types and soil physical 161 parameters. For a more detailed description of MOLOCH refer to Buzzi et al. (2014).

162 In the present study, the NWP system was applied to six case studies (Table 1). First, a thorough 163 verification of the simulations was performed in order to verify that the model correctly reproduced 164 the main dynamical features of each event. Model simulations were compared with observations, 165 such as the dense ground-based station networks (which observed near-surface temperature, wind, 166 humidity and precipitation), radiosoundings and operational wind profilers over northern Italy, in 167 order to assess the mesoscale features. The large-scale dynamics was compared against ECMWF 168 analyses. No special observations, except for some additional soundings, were available over the 169 NEI area for IOP18 and IOP19 events. However, it is worth mentioning that the unprecedented 170 collaboration fostered by the HyMeX-SOP1 among research institutions and regional 171 meteorological centres and agencies (Davolio et al., 2015) allowed a fruitful collaboration and 172 sharing of observation database (national radar composite and raingauge network, among others).

173 For the sake of brevity, only the comparisons concerning the total precipitation are presented.

174 For each case study, different initialization times for BOLAM and for MOLOCH nesting were 175 tested and the best simulation was chosen as the "control run" to investigate each episode. We made 
176 this choice to ensure that the simulation is as close to reality as possible, in terms of location, 177 intensity and evolution of the precipitation, as well as of triggering and organization of the 178 precipitating systems, so as to investigate the physical mechanisms rather than the skill of 179 operational forecasting.

180

\section{3. Heavy precipitation events over NEI}

182 A brief description of the selected events, listed in Table 1, is provided here, based on model 183 simulations and comparisons against available observations. The model simulations are used to 184 investigate the physical mechanisms responsible for the precipitation events in Section 4.

185 From a preliminary analysis, it turned out that all the selected events were driven by similar large186 scale conditions (Figure 2), i.e. a synoptic scale trough extended over the Mediterranean and the 187 low-level flow was southerly, coming from the Adriatic Sea. Moreover, during the initial stage of 188 the events the mesoscale flow features were also similar. The pre-existing cold air over the plain of 189 NEI enhanced the low-level blocking caused by the incoming flow damming up against the Alps 190 (Di Muzio, 2014). This produced a strong deflection (flow around) of the southerly flow by the 191 Alps, causing a barrier wind (Buzzi, 2004). This deflection produced north-easterly wind at the foot 192 of the Alps, initially preventing the warm air from advancing inland towards the mountains.

193 The analysis of the events also showed that, after the initial stage, different mesoscale evolutions 194 were responsible for the different precipitation patterns already mentioned (the low-level flow 195 evolution is thoroughly analysed in Section 4.2). This led us to separate the events into two main 196 categories. Hereafter we refer to "Alpine" events that were characterised by heavy, widespread 197 rainfall over the Alpine area, associated with uplift of the southerly low-level flow over the 198 orographic barrier, which represents the most frequent case in such situations. In addition to IOP19, 199 two recent heavy-precipitation episodes affecting the Alps were also analysed (Table 1). In contrast, 200 we refer to "Upstream" events that were characterised by intense and almost stationary convective 201 precipitation over the plain upstream of the orography, associated with persisting low-level 
202 blocking of the impinging southerly flow. In addition to IOP18, two Upstream events were selected 203 among those discussed in Barbi et al. (2012). However, since the interest is placed on 204 orographically modified flow, we have not considered the other two cases included in the study of 205 Barbi et al. (2012), which were similar in terms of precipitation distribution but characterised by 206 north-easterly Bora wind instead of barrier-type wind.

207 Generally, simulated rainfall showed a better agreement with the observations for the Alpine 208 (Figures 3 and 4 (a), (b), (c)) rather than the Upstream events (Figures 3 and 4 (d), (e), (f)). The 209 direct orographic uplift, which represents a fairly large-scale forcing, is probably better simulated 210 by the model than the local triggering of convection, and may thus account for the larger degree of 211 predictability.

212

\subsection{IOP19}

214 By 4 November 2012, an upper-level trough extended from the Scandinavian Peninsula to the 215 Atlantic Ocean, with a surface pressure minimum close to Ireland. The Mediterranean was affected 216 by intense south-westerly flow in the middle troposphere, while a warm conveyor belt ahead of the 217 cold front advected warm air towards the Italian peninsula (Ferretti et al., 2014). At the surface, the 218 development of a shallow cyclone over the Gulf of Lion, progressively moving towards northern 219 Italy, favoured intense low-level warm and moist southerly flow over the Adriatic Sea. The 220 synoptic pattern (Figure 2(a)) evolved slowly during 4 and 5 November, due to the presence of a 221 pressure ridge over eastern Europe, and was associated with intense precipitation over NEI (Figure 222 3(a)), especially in the areas close to the Slovenian border, where a maximum of $370 \mathrm{~mm}$ in about 22324 hours was observed. While the precipitation was very weak over the plain, intense rainfall, 224 exceeding $200 \mathrm{~mm}$ in 24 hours, was recorded over a wide area of the Alps. However, only a few 225 lightning strikes were detected indicating that the precipitation was mainly stratiform/orographic in 226 nature. This is also supported by low Convective Available Potential Energy (CAPE) values, and 227 moderate vertical motion was only attained during the final phase of the event, as indicated by both 
228 model simulations and data from the Campoformido (Udine) radiosounding (location in Figure 1). 229 MOLOCH correctly simulates the rainfall distribution (Figure 4(a)), although it slightly 230 underestimates the orographic rainfall. Also, the hourly rainfall evolution is in good agreement with 231 radar estimates (not shown), with the heaviest precipitation occurring in the evening over the north232 easternmost sector of NEI Alps. The model simulates a slightly faster passage of the cold front over 233 the area, thus sweeping away the precipitation system about two hours earlier than observed.

234 On the mesoscale, it is worth mentioning that in the initial phase of the event, cold air was present 235 over the plain (average $\theta_{\mathrm{e}}$ was $313 \mathrm{~K}$ close to the ground), and a barrier wind developed ahead of 236 the Alps, due to the westward deflection of the southerly wind coming from the sea, as predicted by 237 MOLOCH and confirmed by wind measurements taken just inland of the Adriatic coast (not 238 shown). The inflow from the sea was initially forced to rise over the cold air. Later, while 239 increasing its intensity, the southerly flow was characterised by a gradual transition from flow240 around to flow-over conditions, associated with the removal of the cold air at the base of the 241 orography. The uplift was then directly forced by the passage over the Alps, where most of the 242 precipitation occurred (Figure 3(a)).

\section{$244 \quad 3.2$ Piancavallo 2012}

245 Between 10 and 11 November 2012, just a few days after the end of the SOP1, a trough deepened 246 over the Iberian Peninsula (Figure 2(b)), reaching Northern Africa and activating intense warm and 247 moist south-westerly flow over the central Mediterranean. The eastward evolution of the trough was 248 very slow and a cut-off low eventually formed over Spain. The low-level moist flow over the 249 Adriatic Sea produced heavy rainfall (almost $400 \mathrm{~mm}$ in 24 hours) over the Pre-Alpine area (Figure 250 3(b)), between Veneto and FVG regions, while precipitation was light over the plain. MOLOCH 251 correctly simulates the orographic precipitation (Figure 4(b)) although the maximum accumulation 252 is underestimated by about $20 \%$ (310 mm instead of 390 in 24 hours at Piancavallo, over the FVG 253 Alps; Table 1). Similar to IOP19 event, the Sirocco wind, initially deflected ahead of the Alpine 
254 barrier, progressively penetrated inland, gently rising over the Alps. Again, this wind pattern is 255 confirmed by SODAR wind profile measurements (not shown). During the most intense phase of 256 the event, MOLOCH simulates vertical velocities of a few $\mathrm{m} \mathrm{s}^{-1}$ within the precipitation system, 257 indicating the probable development of embedded convection.

258

259

\subsection{Vicenza 2010}

260 This event was a long-lasting episode of intense precipitation, leading to a major river flood in the 261 city of Vicenza (location in Figure 1). After weak rainfall during the morning of 31 October 2010, 262 moderate to heavy precipitation developed over the Pre-Alpine area, persisting into 1 November, 263 while only weak rainfall affected the plain. As in the previous cases, rainfall was associated with a 264 deep trough over the Mediterranean basin (Figure 2(c)), evolving into a cut-off low over the Gulf of 265 Lion in the final phase. A reinforcing ridge over eastern Europe slowed the eastward progression of 266 the trough, thus favouring the stationarity of the intense low-level Sirocco wind over the Adriatic 267 Sea and the persistence of precipitation. The location of intense rainfall was strictly correlated with 268 orographic features along a WSW-ENE direction over the Pre-Alps (Figure 3(c)) and the pattern did 269 not change throughout 31 October and 1 November. The most intense phase of the event was 270 characterised by rainfall reaching $460 \mathrm{~mm}$ in 48 hours in Veneto and about $600 \mathrm{~mm}$ in 48 hours in 271 FVG. However, considering the whole 72-hour period of rainfall, more than $700 \mathrm{~mm}$ were recorded 272 in FVG and more than $500 \mathrm{~mm}$ in several stations in the Veneto region. As shown in Figure 4(c) 273 MOLOCH correctly simulates the precipitation pattern, displaying intense rainfall over the Alps. 274 The hourly evolution (not shown) is properly simulated, with increasing rain rate in the morning of 2751 November, possibly associated with embedded convective activity, and rainfall progressively 276 weakening in the afternoon, eventually becoming scattered. Also in this case, the initially weak 277 low-level south-easterly flow from the Adriatic Sea was blocked and deflected as a barrier wind, 278 but as it increased in intensity, it was able to flow over the Alps. This feature is confirmed by 
279 SODAR wind profile observations (Figure 5(a)) taken in Concordia Sagittaria close the Adriatic 280 coast (location in Figure 1).

281

282

\subsection{IOP18}

283 On the morning of 31 October 2012, a secondary cyclone developed over Spain, embedded in a 284 larger cyclonic circulation centred north of the British Isles. This low-pressure system moved 285 eastward over the Gulf of Lion reaching Corsica in the afternoon (Figure 2(d)) and inducing low286 level south-easterly moist unstable flow over the Adriatic area, impinging on the Alps, and south287 westerly flow aloft. In contrast to the previous events, here the low-level intense currents over the 288 Adriatic basin were not able to pass over the Alps during the whole event and the persisting 289 convergence line between the Sirocco wind and the barrier wind focused the convective activity 290 over the Veneto plain, just north of the Po river outlet. Radar images (not shown) revealed that 291 initially the rainfall was produced in the early afternoon of 31 October by convective systems 292 triggered over the Adriatic Sea and then advected inland over the Po Valley. This phase of the event 293 is reproduced with some delay in $\mathrm{MOLOCH}$, which simulates intense rainfall over the plain only 294 after 1700 UTC. Later in the evening of 31 October, almost stationary convection developed over 295 the plain, related to the convergence line. Although the complete picture of simulated rainfall is 296 affected by a significant error in the location (Figure 4(d)), the simulation captures correctly the 297 dynamical evolution of the low-level flow and of the convergence line, as well as the total rainfall. 298 Therefore, the model reproduces the convective activity and its stationarity, but slightly later than 299 observed. In less than 12 hours, intense precipitation exceeding $120 \mathrm{~mm}$ affected a restricted area of 300 NEI (Figure 3(d)). For some raingauge stations the return period of the event was calculated to be 301 longer than 50 years. However, the rapid eastward progression of the cyclone moved the 302 precipitation away. Observation revealed that wind gusts over the Adriatic exceeded $80 \mathrm{~km} \mathrm{~h}^{-1}$ (not 303 shown) and a major storm surge affected the NEI coast. 


\section{$305 \quad 3.5$ Marghera 2007}

306 This event, thoroughly described and investigated in Davolio et al. (2009b) and Rossa et al. (2010),

307 was the most intense rainfall episode that occurred during the operational period of the MAP308 DPHASE project (Rotach et al., 2009). It was responsible for a severe, although localised, flood 309 over a flat area near Venice (location in Figure 1) on 26 September 2007. It was associated with a 310 stationary mesoscale convective system (MCS) that developed west of the Venice lagoon (Barbi et 311 al., 2012), and took a V-shape in infrared satellite imagery (Setvák et al., 2013). More than $320 \mathrm{~mm}$ 312 fell in less than 12 hours (Figure 3(e)), of which more than $240 \mathrm{~mm}$ fell in only 3 hours. An upper313 level trough, deepening over France and the Mediterranean while approaching the western Alps 314 (Figure 2(e)), favoured orographic cyclogenesis over the Gulf of Genoa and produced a south315 westerly diffluent flow over NEI. The orographically-induced cyclone enhanced the south-easterly 316 low-level jet over the Adriatic Sea, which was deflected in front of the Alpine barrier. The MCS 317 was triggered along the convergence line between the Sirocco wind and the barrier wind. 318 MOLOCH simulates scattered convective activity in the early morning, turning into organised 319 convection able to produce large rain rate up to $180 \mathrm{~mm} \mathrm{~h}^{-1}$ close to the Venice lagoon (Figure 320 4(e)). Low-level convergence, stationary convection, as well as the orientation of the V-shape 321 structure of the MCS are correctly simulated. Differences between the structure of the observed and 322 forecast rainfall fields remain within the expected variability for this particular event, as discussed 323 in Davolio et al. (2009). Finally, the persistence of blocked-flow conditions and of the barrier wind 324 over the NEI plain is confirmed by SODAR observations (Figure 5(b)) taken close to the city of 325 Padua (location in Figure 1).

\subsection{Mira 2009}

On 16 September 2009 the synoptic circulation was characterised by a cyclonic disturbance over the western Mediterranean basin (Figure 2(f)) and south-westerly flow in the middle troposphere over NEI. The cut-off cyclone centred between Spain and France induced moist south-easterly flow 
331 in the lower levels over the Adriatic Sea. Again, the interaction between the north-easterly barrier

332 wind in front of the Alps and the Sirocco wind produced a convergence pattern able to trigger 333 convective activity over the Veneto plain, close to the Venice lagoon. In the early morning 334 convective cells moved from the Adriatic Sea towards the Pre-Alpine ridge and later became more 335 stationary, regenerating along the coastal area. Around 1200 UTC, a stationary MCS developed 336 producing intense rainfall. This evolution explains the precipitation pattern shown in Figure 3(f) 337 characterised by a main maximum of about $180 \mathrm{~mm}$ in 24 hours close to the coast and weaker 338 localised maxima over the Pre-Alps. The MOLOCH simulation of this event is not completely 339 satisfactory (Figure 4(f)), but reproduces the most intense phase of stationary convection around 3401200 UTC, which is the most relevant aspect for this study. Indeed, a rainfall maximum is 341 simulated over the plain, although displaced south-westward and less intense of the maximum over 342 the orography.

344 4. Physical mechanisms

\section{$345 \quad$ 4.1 Theoretical framework}

346 The cases summarised in Section 3 are characterised by the interaction of moist and warm flow 347 with a mountain ridge. Before presenting a detailed investigation of the events in terms of physical 348 mechanisms and numerical parameters, a brief review of the main scientific achievements in the 349 field of orographically modified flow and orographic precipitation is provided, highlighting the 350 framework and motivation of the present study.

351 Idealised studies of stably-stratified dry flows impinging on a mountain ridge revealed the Froude 352 number $(\mathrm{Fr}=\mathrm{U} /(\mathrm{N} \cdot \mathrm{h})$ where $\mathrm{U}$ is a measure of the wind speed, $\mathrm{h}$ is a typical height of the mountain 353 and $\mathrm{N}$ is the static stability) as the main parameter able to discriminate between a "flow-over" 354 regime, when the flow passes over the ridge without being significantly deflected $(\mathrm{Fr}>1)$, and a 355 "flow-around" regime, when the flow is blocked in the lower layers and deflected by the ridge (Fr $<$ 356 1) (Smolarkievicz and Rotunno, 1990). Pierrehumbert and Wyman (1985) evaluated the upstream 
357 influence of the orography and showed that upstream blocking and flow diversion in a rotating

358 atmosphere is strictly connected with barrier winds that are generated as a consequence of the

359 damming of low-level stable air. This aspect is particularly relevant as a theoretical support for the 360 observed phenomenon of barrier wind over NEI described in Section 3.

361 The introduction of moisture, which modifies the "effective" static stability $\mathrm{N}$ of the air at 362 saturation and hence the dynamical response to orographic forcing, depending on when and where 363 condensation occurs, may favour the flow-over regime (e. g. Miglietta and Buzzi, 2004). In the last 364 decade, attention has been mainly focussed on conditionally unstable moist flow and on regimes of 365 convection propagation in presence of orography, pointing out the limited applicability of Fr in such 366 conditions. Chen and Lin (2005) and Miglietta and Rotunno (2009) found that Fr taken alone is 367 unsuitable to explain the precipitation distribution in a convective environment. Thus, Miglietta and 368 Rotunno $(2009,2010)$ introduced several non-dimensional parameters to account for orographic 369 triggering of convection in conditionally unstable flow and subsequent interactions between the 370 environmental flow and the convective cold pool. In particular, the parameter $\mathrm{h}_{\mathrm{m}} / \mathrm{LFC}$, namely the 371 ratio between ridge height $\left(\mathrm{h}_{\mathrm{m}}\right)$ and the altitude of the level of free convection (LFC), was suggested 372 to quantify the likelihood that orographic lifting is sufficient to initiate convection.

373 In addition to idealised simulations, important results came also from case studies analyses, mostly 374 fostered by field campaigns (Rotunno and Houze, 2007). Buzzi and Foschini (2000) and Rotunno 375 and Ferretti $(2001,2003)$ identified important aspects of Alpine heavy rainfall episodes, both at the 376 synoptic- and meso-scale, like the presence of low-level jets and along-ridge gradients of relative 377 humidity able to influence flow ascent through condensation and latent heating. More recently, the 378 dynamics of a low-level moist jet interacting with a complex-shaped ridge has been studied in 379 Nuissier et al. (2008) and Bresson et al. (2009, 2012). They showed that the location of convection 380 triggering and the characteristics of the MCS, in terms of stationarity and accumulated rainfall, 381 depend on different environmental parameters, such as ridge shape, low-level horizontal wind and 382 humidity profiles, CAPE and upstream cold pool features. Finally, the characterisation of the 
383 environment associated with heavy precipitation, in particular concerning the thermodynamic 384 properties of the low-level jet, has been also explored through a climatological approach (Rudari et 385 al., 2004; Ricard et al., 2012).

386 In analogy with the above-mentioned findings, we tried to apply the theoretical results to the 387 observed cases, in order to identify parameters able to describe the different behaviour observed for 388 Upstream and Alpine events. However, it is worth bearing in mind that in real case studies the 389 environment is more complex than in idealized experiments.

390

\subsection{Overview of the dynamical evolution}

392 The dynamical characteristics of the flow interacting with the Alpine orography are preliminarily 393 investigated computing the moist Fr using a vertical profile obtained as an average over an area of 394 about $50 \times 50 \mathrm{~km}$ centred in $45^{\circ} \mathrm{N}-13^{\circ} \mathrm{E}$ (shown in Figure 7). This area, located in the middle of 395 the northern Adriatic Sea, is chosen to sample the mesoscale incoming flow upstream of the 396 orography. Fr is computed every three hours, starting from the onset of impinging flow and until the 397 flow in the area can be considered not yet perturbed by the interaction with the orography or by the 398 occurrence of intense rainfall. However, several drawbacks emerge preventing us from the 399 possibility to identify clearly the two separate classes of events using Fr. In fact, in addition to the 400 known difficulties arising in Fr computation in the case of conditionally unstable flow (Miglietta 401 and Rotunno, 2009), even for almost stratified flow as in the Alpine events results do not 402 completely meet expectations. Fr is computed using $\mathrm{h}=2000 \mathrm{~m}$ for orography height, averaging the 403 meridional component of the wind over the model levels up to this height, and evaluating the flow 404 stability as suggested in Barrett et al. (2014):

$405 \quad N^{2}=\frac{g}{\theta_{t}} \frac{\theta_{t}-\theta_{b}}{h}$

406 where $\mathrm{g}=9.81 \mathrm{~m} \mathrm{~s}^{-2}$ while $\theta_{\mathrm{b}}$ and $\theta_{\mathrm{t}}$ are respectively virtual potential temperature at the lowest 407 model level and at the model level corresponding to about $2000 \mathrm{~m}$. Fr values barely exceed one 
408 (Figure 6), as it would be expected in case of flow-over regime. However, a more detailed analysis 409 reveals a strong horizontal gradient of Fr values across the Adriatic basin for the Alpine events, and 410 thus a strong sensitivity to the selected area of computation. In particular, Fr values much larger 411 than unity are found on the eastern side of the Adriatic basin, while values lower than unity 412 characterise the flow close to the Italian coast. Thus, instead of considering the absolute Fr value, 413 whose computation may be somewhat arbitrary, the attention is focused on its evolution in time. 414 Figure 6 shows that for all the three Alpine events Fr steadily and substantially increases during the 415 event. This is consistent with blocked-flow and barrier wind conditions at the beginning of the 416 event and a gradual change towards a flow-over regime, starting from the easternmost part of the 417 Alps, as simulated by MOLOCH and confirmed by available observations (soundings and wind 418 profilers, e.g. in Figure 5(a)). On the other hand, for the Upstream events and especially for M2007 419 and M2009 cases, Fr values remain low, hardly exceeding 0.6. The exceptionally strong wind 420 attained during IOP18 is responsible for a temporary increase of Fr, although not higher than 0.8. 421 However, in this latter case, the low-level wind is also steered by the mesoscale cyclonic circulation 422 that forces its rotation from the Adriatic Sea into the Po Valley, thus favouring the blocking effect 423 of the Alps. It is also worth noting that Fr for the Alpine events is generally larger than the value 424 obtained for the Upstream events, thus suggesting a different flow regime. Therefore, although the 425 absolute value of Fr does not provide critical information, relative values between different events 426 seem to be able to describe different dynamical characteristics of the analysed events.

427 Keeping in mind these results and the theoretical background briefly described in Section 4.1, the 428 analysis is focussed on two different phases of the events: (i) the triggering phase, being the initial 429 period characterised by the possible development of convective cells and precipitation initiation; (ii) 430 the precipitation phase, when the precipitating system is well developed. For the sake of brevity and 431 clarity, most of the results are presented only for two events, representative of the two categories: 432 V2010 for Alpine events and M2007 for Upstream events. 


\section{$434 \quad$ 4.3 The triggering phase}

435 During the initial phase of both events, the low-level wind field (Figures 7 (a), (b)) displays a 436 similar pattern, characterised by blocked flow upstream of the Alps, possibly enhanced by the 437 presence of pre-existing cold air (Pierrehumbert and Wyman, 1985), producing a north-easterly 438 barrier wind over the NEI plain and over the Po Valley. The convergence between the barrier wind 439 and the Sirocco wind from the Adriatic Sea clearly show up in Figure 7 as a narrow zone of low 440 wind speed. However, the consequence of this convergence is quite different, as shown by the cross 441 sections drawn along the direction of the impinging flow. On one hand, for V2010 case (Figure 442 8(a)) the moist south-easterly flow gently rises over the cold layer located at the foot of the Alps 443 where the barrier wind is blowing, before being further lifted over the orography. No precipitation 444 is associated with the uplift during this phase. On the other hand, in M2007 event (Figure 8(b)) 445 convection is triggered in correspondence with the ascent over the barrier wind cold layer and 446 intense precipitation is suddenly produced.

447 This different behaviour has a critical impact on the following dynamical evolution, when the 448 intensity of the impinging flow increases in response to the approaching synoptic disturbance. As 449 shown in Figures 7(c), in V2010 southerly flow progressively penetrates into the plain, the cold 450 barrier wind layer disappears and the flow eventually passes over the Alps. All over the eastern 451 Alps the 10-m wind field displays a clear flow-over pattern in response to increasing wind speed, 452 while the flow stability remains nearly constant. Consequently, precipitation affects mountainous 453 areas where uplift and condensation occur. The cross section (Figure 8(c)) also indicates some 454 small-scale and intense vertical motions over the orography, possibly due to embedded convective 455 activity that locally enhances rainfall intensity.

456 Conversely, the convergence pattern along the coastal area persists in M2007 (Figure 7(d)). The 457 blocking conditions persist, consistent with the result of the Fr analyses, the low-level flow does not 458 penetrate inland and deep convection intensifies (Figure 8(d)), fed by moist and warm air from the 459 Adriatic Sea. This resembles the blocked-flow condition considered as the most favourable to heavy 
460 rainfall rates in the idealised experiments shown in Miglietta and Rotunno (2014) and in Davolio et

461 al. (2009a), characterised by a convective cold pool propagation nearly countered by the

462 environmental wind. The role of the evaporative cold pool is further discussed in Section 4.5.

463 Now that the general physical mechanisms have been described, a more detailed thermodynamic 464 analysis concerning the initial triggering phase of the events is performed. First, vertical 465 thermodynamic profiles are analysed (Figures 9(a), (b)). Profiles are not computed for a single grid 466 point but as an average over an area of about $15 \times 15 \mathrm{~km}$ over the northern Adriatic Sea, almost 467 contained in the area used for computing Fr. Using an upstream area gives a better sampling of 468 undisturbed flow characteristics before its interaction with the orography and with the cold pool 469 producing uplift and possibly triggering convection. Profiles are computed for the initial phase of 470 the events, when convection is possibly being triggered but intense precipitation has not started yet. 471 These profiles allow for the evaluation of the LFC height and CAPE (using the most unstable 472 parcel) and several indices related to stability (Tables 2 and 3). Similarly, vertical profiles over the 473 NEI plain, together with the analysis of cross sections similar to those presented in Figure 8, 474 provide the estimate of $h_{b}$ as the top of the layer characterised by stable stratification and north475 easterly wind. This layer is found to be quite shallow, with its depth always being lower than 800 $476 \mathrm{~m}$.

477 Although it is possible to identify an LFC located at a relatively high elevation, around 1000 478 meters, the profile for V2010 (Figure 9(a)) shows a nearly neutral moist vertical stratification of the 479 air mass, even stable in the lower layers and with very low CAPE values (below $50 \mathrm{~J} \mathrm{~kg}^{-1}$ ). This is a 480 common characteristic among the Alpine events, with the LFC being even higher in IOP19. The 481 wind veers by about 45 degrees over the lowest $2 \mathrm{~km}$. The moisture content is already high at the 482 beginning of the simulation and the air column becomes saturated quite quickly during the first day 483 of the event (not shown), without relevant changes in stability properties. On the other hand, for 484 M2007 (Figure 9(b)) and similarly for M2009 (not shown) the atmosphere is conditionally unstable, 485 close to saturation in the lowest layers and much drier above $850 \mathrm{hPa}$ where the wind direction 
486 abruptly changes from south-easterly to south-westerly. The LFC is fairly low, being located below $487500 \mathrm{~m}$ and the value of CAPE is relevant, greater than $1000 \mathrm{~J} \mathrm{~kg}^{-1}$. It is worth mentioning that the 488 vertical profile for IOP18 (not shown) is also characterised by a low LFC. However, moisture is 489 higher and more uniform all over the troposphere and CAPE is lower and mainly concentrated in 490 the lower layers, as usually observed for autumn events with respect to late summer cases.

491 The described behaviour is also in agreement with positive values of the Lifted Index (Galway, 492 1956) (LI $>2.2 \mathrm{~K}$, in Table 2) found for the Alpine events, which indicate stable conditions during 493 the initial phase of the event. For the Upstream events (Table 3) potential instability is instead 494 present. This is especially true for M2007 and M2009 events, which have a negative LI, but also for 495 IOP18, even if the LI indicates nearly neutral conditions $(0.5 \mathrm{~K})$. Indeed, referring to a 496 climatological statistical analysis of convective events over the FVG area (Manzato, 2003) a LI of $497+0.64 \mathrm{~K}$ represents the discriminant value to classify convection development in the FVG plain.

498 While it is evident that deep convection cannot develop in the initial stage of the Alpine events, the 499 Upstream events deserve a further analysis of the triggering phase. Among the relevant parameters 500 modulating rainfall rate and location for a conditionally unstable flow over a ridge, Miglietta and 501 Rotunno (2009) suggested to use the ratio of mountain height to the level of free convection $502\left(\mathrm{~h}_{\mathrm{m}} / \mathrm{LFC}\right)$. This parameter evaluates whether the uplift forced by the mountain is sufficient to allow 503 air parcels to reach their LFC and thus to trigger convection. In the present analysis the same idea is 504 adopted, but considering the cold layer with barrier wind, instead of the mountain, as the "obstacle" 505 providing the initial uplift forcing. A similar approach was used by Mazòn and Pino (2013) in their 506 analysis of convective cloud bands developing near the Mediterranean coasts. In other words, this 507 cold layer located upstream of the orography, and characterised by the barrier wind, acts as an 508 “effective mountain" (Lin et al., 2005) of height $h_{b}$.

509 Values of $h_{b} / L F C$ computed for the three Upstream events during the triggering phase are close to 510 or greater than unity, consistent with the fact that convection is triggered where the impinging and 511 barrier flows meet. For IOP18, besides the main rainfall episode that occurs in the late evening 
512 (associated with the highest value of $h_{b} / L F C$ ), an interesting convective phase in the morning is also 513 considered, when shallow convective activity developed over the Adriatic Sea in correspondence 514 with the aforementioned convergence line. Also in this case $h_{b} / L F C$ is close to unity. However, 515 during IOP18, convection is triggered but does not develop into deep convection. Instead, for 516 M2007 and M2009 events, high values of CAPE indicate favourable conditions for vigorous 517 convective vertical motions and heavy rainfall.

518 Another clear indication concerning the type of event can be obtained by considering the buoyancy 519 of air parcels displaced vertically from multiple levels (Davolio et al., 2009a; Buzzi et al., 2014). At 520 each model level, the virtual temperature of an air parcel adiabatically raised by a given 521 displacement is computed and compared with the virtual temperature of the environment at the new 522 altitude. Since early stages of convection are analysed, computation assumes the loading of 523 condensed water (reversible uplift), considers the occurrence of precipitation negligible, and 524 entropy conservation of a mixture of air/vapour/cloud water. The virtual temperature difference 525 between the parcel and the environment, is used to calculate the buoyancy as follows:

$526 \quad B=g \frac{T_{v}^{p a r}-T_{v}^{e n v}}{T_{v}^{e n v}}$

527 Buoyancy is computed as a function of the height of the parcel, thus providing a buoyancy profile 528 relative to more parcels. Figure 10 shows the results for a vertical lift of 500 metres. Similar results 529 hold for slightly different vertical displacements (consistent with the height of the leading edge of 530 the barrier-wind cold layer), small enough to assume that condensed water is still retained by the 531 lifted parcel. The Upstream convective cases are characterised by positive buoyancy, and thus 532 instability to small vertical displacements in the lowest atmospheric layer of depth of roughly 1000 533 metres. The vertical profile of buoyancy for IOP18 is characterised by larger values close to the 534 ground, progressively decreasing aloft. This is consistent with thermodynamic profiles close to 535 saturation, unstable in the lower layers and almost neutral above, with moderate CAPE values. 536 Conversely, M2007 and M2009 thermodynamic profiles (Figure 9(b)) indicate increasing relative 
537 humidity with height in the first 1500 metres, characterised by a lapse rate close to the dry

538 adiabatic. Thus buoyancy shows that the most unstable parcels are located at around 500 metres

539 above the surface and not near the ground. Conversely, buoyancy presents negative values for the 540 Alpine events, indicating overall stable conditions. The buoyancy profile for IOP19 is slightly

541 different between 1000 and $2000 \mathrm{~m}$, but still representative of stability to vertical displacements.

542 In summary, the thermodynamic profile of the impinging southerly flow, which is forced to rise

543 over the cold stable layer located over the plain upstream of the orography, determines the different

544 behaviour observed in the two classes of event. $\mathrm{h}_{\mathrm{b}} / \mathrm{LFC}$ reveals the possible triggering of convection

545 during the first phase of the events, in case of conditional instability. Also LI turns out to be

546 important because it indicates a necessary condition for potential instability in order to realise

547 vigorous convective activity. Once convection is initiated, its intensity is related to CAPE.

549 4.4 Precipitation phase: Alpine events

550 As previously described, if convection is not triggered in correspondence with convergence and

551 uplift, the south-easterly flow is able to progressively penetrate towards the Alps, replacing the pre-

552 existing cold air ahead of the orography. Consistently, a gradual transition from blocked-flow to

553 flow-over conditions is observed. However, model simulations (see for example the cross section in

554 Figure 8(c)), as well as rainfall and remote sensing observations, reveal that convective activity can

555 be embedded in the orographic precipitation, at least in the most intense phase of the events. This is

556 a quite typical characteristic of heavy-precipitation events over north-eastern Alps, usually referred

557 to as flux precipitation (Manzato, 2007), that deserves further investigation.

558 As presented in Section 4.2 for the Alpine episodes, variation of Fr describes the transition to a 559 more pronounced flow-over conditions during the event. Moreover, an analysis of the 560 thermodynamic vertical profiles upstream of the orography reveals that the impinging flow 561 becomes progressively more unstable, and during the precipitation phase slightly unstable 562 conditions are attained. Therefore, the parameter $h_{m} / L F C$ becomes suitable to explain the possible 
563 occurrence of convective activity. In Figure 11, the evolution in time of $h_{m} / L F C$ is plotted for the 564 Alpine events. Values of $\mathrm{h}_{\mathrm{m}}$ /LFC increase progressively, becoming close to or larger than unity in 565 correspondence to the initiation of intense precipitation. This confirms that the uplift forced by the 566 Alps is able to trigger convective activity, since the air parcels are forced to rise above the level of 567 free convection. Moreover, low CAPE values are consistent with the presence of weak to moderate 568 convection, acting to locally enhance rainfall rates. V2010, besides being the longest lasting event, 569 is also characterised by a more pronounced potential for convection development (Figure 11). It is 570 worth noting that rainfall enhancement over the windward slopes of the orography can be also due 571 to small-scale turbulence and microphysical processes (i.e. seeder-feeder mechanism), as described 572 for the western Alps for unblocked low-level flow (Rotunno and Houze, 2007).

573

\section{$574 \quad 4.5$ Precipitation phase and the role of the cold pool in the Upstream events}

575 When convection initiates resulting from uplift over the cold layer, the southerly low-level moist 576 flow is intercepted by the convergence line and hardly reaches the Alps. The convergence line 577 persists almost in the same position for several hours. Thus, although the direct orographic forcing 578 is not the main lifting mechanism, the Alps are responsible for the persisting blocked-flow 579 conditions, as displayed by the Fr analysis in Section 4.2. This can account for the stationarity of 580 the convective systems. However, the formation of evaporative cold pools is crucial in determining 581 organisation and propagation properties of convective systems (Emanuel, 1994). In the present 582 cases, cold-air layer formation precedes the convection onset; however, once convection has 583 developed, cold pools can be reinforced by evaporative cooling and can thus interact with the 584 upstream flow, forcing the low-level flow up and over its head (Bresson et al. 2012; Miglietta and 585 Rotunno 2009). In order to explore this aspect, additional MOLOCH simulations were performed 586 for the three Upstream events. These experiments were similar to their respective control runs, 587 except that the contribution to the temperature tendency due to evaporation or sublimation of 588 precipitation was removed in the microphysics parameterisation scheme. 
589 Figure 12 presents the results for M2007. The accumulated rainfall (Figure 12(a)) indicates that, in 590 this simulation, the convective system persists over the plain of the Veneto region, just inland the 591 Adriatic coast. With respect to the control simulation (Figure 4(e)), the precipitation maximum is 592 shifted about $20 \mathrm{~km}$ to the northeast and displays a different orientation, although the intensity does 593 not differ markedly $(370 \mathrm{~mm} / 12 \mathrm{~h})$. The lack of the precipitation band over the sea, parallel to the 594 coast, reveals the main difference between the two simulations. The triggering phase is very similar, 595 but during the mature stage the evaporative cooling actually reinforces the cold pool. Thus, in the 596 control simulation (Figure 8(d)) the convective system slightly propagates against the low-level 597 environmental flow blowing from the Adriatic Sea, as can be seen comparing Figures 8 (b) and (d). 598 Conversely, without the cooling effect of the evaporation beneath the convective system, the low599 level atmosphere upstream of the Alps is warmer and the signature of the cold pool much less 600 evident (Figure 12 (b)). The convergence line, the convective updraft and hence the precipitation 601 system remain over land, north of the coastline but still upstream of the orography.

602 It is worth mentioning that additional experiments were performed in order to evaluate the 603 respective impact on the cooling of evaporation and sublimation of the precipitation. It turned out 604 that the main contribution comes from rainfall evaporation, since the sublimation of ice 605 microphysical hydrometeors does not change the results significantly, with respect to the control 606 simulations.

607 Similar results were obtained for the other two events. Therefore, such experiments indicate that 608 although evaporation/sublimation of precipitation is able to influence to some extent propagation 609 and hence position of convection, it does not determine the stationarity of the systems. Upstream 610 convergence due to persisting blocked-flow conditions is the primary mechanism producing that 611 stationarity.

612 Following Miglietta and Rotunno (2009), the convective system is triggered and continuously 613 regenerated as expected when $h_{m} /$ LFC is larger than one (Table 3). Moreover, their idealised 614 simulations of conditionally unstable flow past a mountain ridge showed that stationary convection 
615 occurs when the advective time scale $\tau_{\mathrm{a}}$ is longer than the convective time scale $\tau_{\mathrm{c}}$. Although the 616 applicability of theoretical results is not always straightforward for real events (Miglietta and 617 Rotunno 2012, Bresson et al. 2012) an estimation of the proposed non-dimensional parameters is 618 presented in the following. Table 3 lists the relevant parameters, evaluated for upstream conditions: 619 Downdraft Convective Available Potential Energy (DCAPE), CAPE $^{1 / 2} / \mathrm{U}$, which is almost 620 proportional to $\tau_{\mathrm{a}} / \tau_{\mathrm{c}}$, DCAPE $\mathrm{DC}^{1 / 2} / \mathrm{U}$, representing a measure of cold-pool propagation and N LFC / $621 \mathrm{U}$, which evaluates the impact of cold pool propagation on the upstream flow.

622 The results for M2007 and M2009 are very similar and the location of the precipitation seems to be 623 correlated with the theoretical results. Moderate wind speed and large instability (large values of $\left.624 \mathrm{CAPE}^{1 / 2} / \mathrm{U}\right)$ are consistent with a stationary convective system upstream of the mountain ridge, 625 since there is enough time for evaporative reinforcement of the cold pool and redevelopment of 626 convective cells over the same area $\left(\tau_{\mathrm{a}}>\tau_{\mathrm{c}}\right)$. Moreover, the intensity of downdraft indicates the 627 possibility to have a slight propagation of the cold pool against the low-level environmental flow 628 for M2007, as actually observed. For IOP18 the comparison is even more difficult, since it is a low629 CAPE case with very strong wind. Although parameters suggest the triggering of convection, it 630 seems that intense wind speed does not create favourable conditions for long-lasting stationary 631 convection, as instead occurs during M2007 and M2009. It can be argued that in this case other 632 mechanisms could have contributed to the organisation of the convective system. In particular, 633 cyclonic mesoscale forcing could have played a role during the first part of the precipitation phase 634 by advecting convective cells from the Adriatic Sea towards the convergence line and later on 635 favouring the deflection of the low-level flow. The strong vertical shear characterised by a variation 636 of the along-ridge component of the flow could have also affected the convective system evolution 637 (Miglietta and Rotunno, 2014).

638 639

\section{Conclusions}


640 The present study was motivated by observations made during the HyMeX-SOP1 campaign, which

641 documented two heavy-precipitation episodes (IOP18 and IOP19) characterised by similar synoptic

642 situations and initial mesoscale conditions of blocked-flow impinging on the Alpine barrier but with 643 a completely different dynamical evolution, leading to different precipitation patterns. During 644 IOP18, blocked-flow conditions persisted and the low-level south-easterly flow came from the 645 Adriatic Sea and was then deflected in front of the orography as a north-easterly barrier wind, 646 creating a convergence line upstream of the orography, where convection was triggered. Heavy 647 precipitation affected the plain area of NEI well upstream of the orography. Conversely, during 648 IOP19 the south-easterly flow was blocked by the Alps only in the initial phase, but then 649 progressively penetrated inland reaching the Alpine ridge, consistent with flow-over conditions. 650 This situation produced intense rainfall over the orography. This evidence prompted a survey and 651 an analysis of other similar cases, in order to identify common mechanisms leading to two different 652 precipitation patterns over NEI.

653 Notwithstanding the peculiar features and the complexity of each analysed event, the present study, 654 based on high-resolution NWP model simulations validated and supported by observations, shows 655 clearly that the two different rainfall patterns belong to two different "regimes" of precipitation 656 event that often affect the NEI area, as summarised in the schematic diagram of Figure 13. For all 657 the events, the low-level south-easterly flow (Sirocco wind) is initially blocked by the Alps and 658 deflected as an easterly/north-easterly barrier wind over the NEI plain. The presence of pre-existing 659 cold air over the NEI plain, resulting from nocturnal radiative cooling, enhances the low-level 660 blocking. As the synoptic disturbance progresses, the low-level wind intensifies and, depending on 661 the thermodynamic vertical profile of the impinging flow, convective activity may be triggered in 662 the initial phase. In the Upstream events (Figure 13(a)), convection initiates well upstream of the 663 orography where the incoming flow is forced to rise over the cold layer characterised by the barrier 664 wind. Blocked-flow conditions persist and the convergence line between the Sirocco wind and the 665 barrier wind triggers further convection. The cold pool is even reinforced by evaporative cooling of 
666 the convective precipitation, but specific model simulations have proved that the stationarity of the 667 convective system is determined by the persisting blocked-flow conditions by the Alps, confirmed 668 by low Fr values. The low-level flow from the Adriatic Sea is intercepted and thus it feeds the 669 convection and does not reach the orography. Therefore, precipitation affects the NEI plain or even 670 the coastal area, far upstream from the Alps.

671 In the Alpine events (Figure 13(b)) convection does not develop as a result of the forced uplift over 672 the cold air. Flow-over conditions progressively become established and the low-level flow coming 673 from the Adriatic Sea reaches the Alps, while the cold air ahead of the orography is removed. This 674 is also supported by progressively increasing values of Fr. The barrier wind disappears and the 675 orographically forced uplift of the impinging flow produces intense precipitation over the Alps.

676 Therefore, rainfall location turns out to be the consequence of different dynamical behaviour of the 677 flow impinging on the orography and its thermodynamics characteristics are critical for the 678 triggering of convective activity due to uplift over the barrier wind cold layer. If the profile is 679 unstable and the LFC is located at low altitude, this uplift is strong enough to trigger convection 680 over the plain upstream. Indices such as LI, CAPE, TLIFT and $h_{b} / L F C$ proved able to take into 681 account the mechanisms responsible for the different phenomena observed during the triggering 682 phase.

683 The results obtained for the convective events are in agreement with theoretical studies of 684 conditionally unstable flow over orography. The value of $\mathrm{h}_{\mathrm{m}} / \mathrm{LFC}$ much greater than unity indicates 685 occurrence of convection upstream of the orography and the other parameters indicate an 686 environment favourable for cold-pool development and triggering of convective cells upstream of 687 the mountains. As observed during the M2007 and M2009 events, stationary deep convection 688 develops and persists on the same area as the convective cold-pool propagation is nearly balanced 689 by the environmental inflow. Only IOP18 does not fit completely with the theoretical results. Low690 CAPE values and strong wind speed make this case quite particular and it is difficult to refer it to 691 idealised simulations proposed in the literature. However, for all the three Upstream events the 
692 evaporative cooling beneath the precipitation system plays only a secondary role in determining the

693 characteristics of the convective system. Indeed, stationarity of the convergence line and of the

694 convection upstream of the Alps is mainly ascribable to the persistence of blocked-flow conditions.

695 For these events, convective outflow can only slightly modify rainfall position and intensity.

696 Finally, $\mathrm{h}_{\mathrm{m}} / \mathrm{LFC}$ is also computed for the Alpine events during the intense precipitation phase, when

697 the thermodynamic profile of the impinging flow becomes unstable. Here, $\mathrm{h}_{\mathrm{m}} / \mathrm{LFC}$ confirms the 698 possible development of convection, embedded in the orographic stratiform precipitation, 699 responsible for locally enhancing the rain rates.

700 Several other aspects will be explored in future studies. The role of neighbouring mountain ranges 701 (Apennines and Dinaric Alps) will be investigated as well as the role of intense air-sea interactions 702 on water vapour budget and boundary layer characteristics. Moreover, the analysis of additional 703 heavy-precipitation events will possibly provide a more robust statistical support to these results.

706 Acknowledgements: This work represents a contribution to the HyMeX program. This work was 707 supported by the Italian flagship project RITMARE. The authors are grateful to two anonymous 708 reviewers for their pertaining remarks and comments, which helped improve this manuscript. The 709 authors thank Dr. Anna Fornasiero for providing radar images during the early stages of the study, 710 and Dr. Mario Miglietta, Dr. Andrew Barrett and Dr Andrea Buzzi for fruitful discussions and 711 relevant suggestions. Thanks also to Nick Byrne for having carefully read the manuscript. The 712 authors wish to thank all the participants to the Italian national operational centre during the SOP1 713 field campaign: CNR (ISAC, IBIMET, IMAA), CETEMPS, Università La Sapienza, ISPRA, 714 Università Parthenope, OSMER-ARPA FVG, ARPA Piemonte, ARPAV, ARPA-SIMC, LaMMA, 715 ARPAL, Centro Funzionale Abruzzo, Centro Funzionale Marche, Centro Funzionale Umbria. 716 Thanks also to the National Department of Civil Protection (DPC) and to the CIMA foundation for 717 providing data of the national raingauge and radar network. 


\section{REFERENCES}

720 Barbi A, Monai M, Racca R, Rossa AM. 2012. Recurring features of extreme autumnal rainfall 721 events on the Veneto coastal area. Nat. Hazards Earth Syst. Sci. 12: 2463-2477.

722 Barrett A, Gray S, Kirshbaum D, Nigel R, Schultz D, Fairman JG. 2014. Synoptic versus 723 orographic control on stationary convective banding. Q. J. R. Meteorol. Soc. 141: 1101-1113.

724 Billet S, Toro EF. 1997. On WAF-type schemes for multidimensional hyperbolic conservation 725 laws. J. Comput. Phys. 130: 1-24.

726 Borga M, Boscolo P, Zanon F, Sangati M. 2007. Hydrometeorological analysis of the 29 August 7272003 flash flood in the Eastern Italian Alps. J. Hydrometeorol. 8: 1049-1067.

728 Bougeault P, Binder P, Buzzi A, Dirks R, Kuettner J, Smith RB, Steinacker R, Volkert H. 2001. 729 The MAP special observing period. Bull. Amer. Meteorol. Soc. 82: 433-462.

730 Bousquet O, Smull BF. 2003. Observations and impacts of upstream blocking during a widespread 731 orographic precipitation event. Q. J. R. Meteorol. Soc. 129: 391-410.

732 Bresson R, Ricard D, Ducrocq V. 2009. Idealized mesoscale numerical study of Mediterranean 733 heavy precipitating convective systems. Meteorol. Atmos. Phys. 103: 45-55.

734 Bresson R, Ducrocq V, Nuissier O, Ricard D, de Saint-Aubin C. 2012. Idealized numerical 735 simulations of quasi-stationary convective systems over the Northwestern Mediterranean complex 736 terrain. Q. J. R. Meteorol. Soc. 138: 1751-1763.

737 Buzzi A. 2004. Heavy precipitation and Alpine orography. In Proceedings of the International 738 Workshop on timely warnings of heavy precipitation episodes and flash floods, Ljubljana, Slovenia, $73912 \mathrm{pp}$.

740 Buzzi A, Foschini L. 2000. Mesoscale meteorological features associated with heavy precipitation 741 in the southern Alpine region. Meteorol. Atmos. Phys. 72: 131-146.

742 Buzzi A, D'Isidoro M, Davolio S. 2003. A case study of an orographic cyclone south of the Alps 743 during the MAP SOP. Q. J. R. Meteorol. Soc. 129: 1795-1818. 
744 Buzzi A, Davolio S, Malguzzi P, Drofa O, Mastrangelo D. 2014. Heavy rainfall episodes over 745 Liguria of autumn 2011: numerical forecasting experiments. Nat. Hazards Earth Syst. Sc. 14: 1325 7461340.

747 Chen SH, Lin YL. 2005. Effects of moist Froude number and CAPE on a conditionally unstable 748 flow over a mesoscale mountain ridge. J. Atmos. Sci. 62: 331-350.

749 Davolio S, Buzzi A, Malguzzi P. 2009a. Orographic triggering of long-lived convection in three 750 dimensions. Meorol. Atmos. Phys., 103, 35-44.

751 Davolio S, Mastrangelo D, Miglietta MM, Drofa O, Buzzi A, Malguzzi P. 2009b. High resolution 752 simulations of a flash flood near Venice. Nat. Hazards Earth Syst. Sci. 9: 1671-1678.

753 Davolio S, Miglietta MM, Diomede T, Marsigli C, Montani A. 2013. A flood episode in Northern 754 Italy: multi-model and single-model mesoscale meteorological ensembles for hydrological 755 predictions. Hydrol. Earth Syst. Sci. 17: 1-14.

756 Davolio S, Ferretti R, Baldini L, Casaioli M, Cimini D, Ferrario ME, Gentile S, Loglisci N, Maiello 757 I, Manzato A, Mariani S, Marsigli C, Marzano FS, Miglietta MM, Montani A, Panegrossi G, Pasi F, 758 Pichelli E, Pucillo A, Zinzi A. 2015. The role of the Italian scientific community in the first HyMeX 759 SOP: an outstanding multidisciplinary experience. Meteorol. Zeit., doi:10.1127/metz/2015/0624.

760 Di Muzio E. 2014: Climatological characterization and dynamics of barrier winds in the Italian 761 region. PhD Thesis, http://amslaurea.unibo.it/6688 (accessed 02 October 2015).

762 Doswell CA, Ramis C, Romero R, Alonso S. 1998. A diagnostic study of three heavy precipitation 763 episodes in the western Mediterranean. Weather Forecasting. 13: 102-124.

764 Drobinski P, Ducrocq V, Alpert P, Anagnostou E, Béranger K, Borga M, Braud I, Chanzy A, 765 Davolio S, Delrieu G, Estournel C, Filali Boubrahmi N, Font J, Grubisic V, Gualdi S, Homar V, 766 Ivancan-Picek B, Kottmeier C, Kotroni V, Lagouvardos K, Lionello P, Llasat MC, Ludwig W, 767 Lutoff C, Mariotti A, Richard E, Romero R, Rotunno R, Roussot O, Ruin I, Somot S, Taupier768 Letage I, Tintore J, Uijlenhoet R, Wernli H. 2014. HyMeX, a 10-year multidisciplinary program on 769 the Mediterranean water cycle. Bull. Amer. Meteorol. Soc. 95: 1063-1082. 
770 Drofa OV, Malguzzi P. 2004. Parameterization of microphysical processes in a non hydrostatic 771 prediction model. In Proceedings of 14th International Conference on Clouds and Precipitation, 772 Bologna, Italy, 1297-1300.

773 Ducrocq V, Braud I, Davolio S, Ferretti R, Flamant C, Jansa A, Kalthoff N, Richard E, Taupier774 Letage I, Ayral PA, Belamari S, Berne A, Borga M, Boudevillain B, Bock O, Boichard JL, Bouin 775 MN, Bousquet O, Bouvier C, Chiggiato J, Cimini D, Corsmeier U, Coppola L, Cocquerez P, Defer 776 E, Delanoë J, Di Girolamo P, Doerenbecher A, Drobinski P, Dufournet Y, Fourrié N, Gourley JJ, 777 Labatut L, Lambert D, Le Coz J, Marzano FS, Molinié G, Montani A, Nord G, Nuret M, Ramage 778 K, Rison B, Roussot O, Said F, Schwarzenboeck A, Testor P, Van Baelen J, Vincendon B, Aran M, 779 Tamayo J. 2014. HyMeX-SOP1, the field campaign dedicated to heavy precipitation and flash 780 flooding in the northwestern Mediterranean. Bull. Amer. Meteorol. Soc. 95: 1083-1100.

781 Emanuel K. A. 1994. Atmospheric Convection. Oxford University Press, 580 pp.

782 Ferretti R, Pichelli E, Gentile S, Maiello I, Cimini D, Davolio S, Miglietta MM, Panegrossi G, 783 Baldini L, Pasi F, Marzano FS, Zinzi A, Mariani S, Casaioli M, Bartolini G, Loglisci N, Montani A, 784 Marsigli C, Manzato A, Pucillo A, Ferrario ME, Colaiuda V, Rotunno R. 2014. Overview of the 785 first HyMeX Special Observation Period over Italy: observations and model results. Hydrol. Earth 786 Syst. Sci. 18:1953-1977.

787 Frei C, Schär C. 1998. A precipitation climatology of the Alps from high-resolution rain-gauge 788 observations. Int. J. Climatol. 18: 873-900.

789 Galway JG. 1956. The lifted index as a predictor of latent instability. Bull. Amer. Meteorol. Soc. 37: $790 \quad 528-529$.

791 Isotta FA, Frei C, Weilguni V, Percec Tadic M, Lassegues P, Rudolf B, Pavan V, Cacciamani C, 792 Antolini G, Ratto SM, Munari M, Micheletti S, Bonati V, Lussana C, Ronchi C, Panettieri E, 793 Marigo G, Vertacnik G. 2013. The climate of daily precipitation in the Alps: development and 794 analysis of a high-resolution grid dataset from pan-Alpine rain-gauge data. Int. J. Climatol. 34: $795 \quad 1657-1675$. 
796 Kain JS. 2004. The Kain-Fritsch convective parameterization: an update. J. Appl. Meteorol. 43:

$797 \quad 170-181$.

798 Lin YL, Reeves HD, Chien SY, Chiao S. 2005. Formation mechanisms for convection over 799 Ligurian Sea during MAP IOP-8. Mon. Weather Rev. 133: 2227-2245.

800 Malguzzi P, Grossi G, Buzzi A, Ranzi R, Buizza R. 2006. The 1966 'century' flood in Italy: A 801 meteorological and hydrological revisitation. J. Geophys. Res. 111: D24106, 802 doi:10.1029/2006JD007111.

803 Manzato A. 2003. A climatology of instability indices derived from Friuli Venezia Giulia 804 soundings, using three different methods. Atmos. Res. 67-68: 417-454.

805 Manzato A. 2007. The 6 h climatology of thunderstorms and rainfalls in the Friuli Venezia Giulia 806 plain. Atmos. Res. 83: 336-348.

807 Manzato A, Davolio S, Miglietta MM, Pucillo A, Setvak M. 2015. 12 September 2012: A supercell 808 outbreak in NE Italy? Atmos. Res. 153: 98-118.

809 Manzato A, Cicogna A, Pucillo A. 2015. 6-hour maximum rain in Friuli Venezia Giulia: 810 climatology and ECMWF-based forecasts. Atmos. Res. doi:10.1016/j.atmosres.2015.07.013 In 811 press.

812 Massacand AC, Wernli H, Davies HC. 1998. Heavy precipitation on the Alpine southside: an 813 upper-level precursor. Geophys. Res. Lett. 25: 1435-1438.

814 Mazòn J, Pino D. 2013. The role of sea-land air thermal difference, shape of the coastline and sea 815 surface temperature in the nocturnal offshore convection. Tellus A 65: 1-13.

816 Miglietta MM, Buzzi A. 2004. A numerical study of moist stratified flow regimes over isolated 817 topography. Q. J. R. Meteorol. Soc. 130: 1749-1770.

818 Miglietta MM, Rotunno R. 2005. Simulations of moist nearly neutral flow over a ridge. J. Atmos. 819 Sci. 62: 1410-1427.

820 Miglietta MM, Rotunno R. 2009. Numerical simulations of conditionally unstable flows over a 821 ridge. J. Atmos. Sci. 66: 1865-1885. 
822 Miglietta MM, Rotunno R. 2010. Numerical simulations of low-CAPE flows over a mountain 823 ridge. J. Atmos. Sci. 67: 2391-2401.

824 Miglietta MM, Rotunno R. 2014. Numerical simulations of sheared conditionally unstable flows 825 over a mountain ridge. J. Atmos. Sci. 71: 1747-1762.

826 Morcrette JJ, Barker HW, Cole JNS, Iacono MJ, Pincus R. 2008. Impact of a new radiation 827 package, McRad, in the ECMWF Integrated Forecasting System. Mon. Weather. Rev. 136: 47738284798.

829 Monai M, Rossa AM, Bonan C. 2006. Partitioning of snowy and rainy precipitation in a case of a 830 north Adriatic frontal passage. Advances in Geosciences 7: 279-284.

831 Nuissier O, Ducrocq V, Ricard D, Lebeaupin C, Anquetin S. 2008. A numerical study of three 832 catastrophic precipitating events over southern France. I: Numerical framework and synoptic 833 ingredients. Q. J. R. Meteorol. Soc. 134: 111-130.

834 Pierrehumbert RT, Wyman B. 1985. Upstream effects of mesoscale mountains. J. Atmos. Sci. 42: $835977-1003$.

836 Ricard D, Ducrocq V, Auger L. 2012. A climatology of the mesoscale environment associated with 837 heavily precipitating events over a northwestern Mediterranean area. J. Appl. Meteorol. Climatol. $838 \quad$ 51: 468-488.

839 Rudari R, Entekhabi D, Roth G. 2004. Terrain and multiple-scale interactions as factors in 840 generating extreme precipitation events. J. Hydrometeorol. 5, 390-404.

841 Ritter B, Geleyn JF. 1992. A comprehensive radiation scheme for numerical weather prediction 842 models with potential applications in climate simulations. Mon. Weather. Rev. 120: 303-325.

843 Rossa AM, Cenzon G, Monai M. 2010. Quantitative comparison of radar QPE to rain gauges for 844 the 26 September 2007 Venice Mestre flood. Nat. Hazards Earth Syst. Sci. 10: 371-377.

845 Rotach MW, Ambrosetti P, Ament F, Appenzeller C, Arpagaus M, Bauer HS, Behrendt A, Bouttier

846 F, Buzzi A, Corazza M, Davolio S, Denhard M, Dorninger M, Fontannaz L, Frick J, Fundel F, 847 Germann U, Gorgas T, Hegg C, Hering A, Keil C, Liniger MA, Marsigli C, McTaggart-Cowan R, 
848 Montani A, Mylne K, Ranzi R, Richard E, Rossa A, Santos-Muñoz D, Schär C, Seity Y, Staudinger

849 M, Stoll M, Volkert H, Walser A, Wang Y, Werhahn J, Wulfmeyer V, Zappa M. 2009. MAP D-

850 PHASE: Real-time Demonstration of Weather Forecast Quality in the Alpine Region. Bull. Amer.

851 Meteorol. Soc. 90: 1321-1336.

852 Rotunno R, Ferretti R. 2001. Mechanisms of intense Alpine rainfall. J. Atmos. Sci. 58: 1732-1749.

853 Rotunno R, Ferretti R. 2003. Orographic effects on rainfall in MAP cases IOP2b and IOP8. Q. J. R.

854 Meteorol. Soc. 129: 373-390.

855 Rotunno R, Houze RA. 2007. Lessons on orographic precipitation from the Mesoscale Alpine

856 Programme. Q. J. R. Meteorol. Soc. 133: 811-830.

857 Schwerdtfeger W. 1984. Weather and Climate of the Antarctic. Elsevier Sciences Publisher, 261 pp.

858 Smith RB. 1979. The influence of mountains on the atmosphere. Advances in Geophysics 21: 87859230.

860 Setvák M, Bedka K, Lindsey DT, Sokol A, Charvát Z, Št’ástka J, Wang PK. 2013. A-Train 861 observations of deep convective storm tops. Atmos. Res. 123: 229-248.

862 Smolarkiewicz PK, Rotunno R. 1990. Low Froude number flow past three-dimensional obstacles.

863 Part II: Upwind flow reversal zone. J. Atmos. Sci. 47: 1498-1511.

864 Zampieri M, Malguzzi P, Buzzi A. 2005. Sensitivity of quantitative precipitation forecasts to 865 boundary layer parameterization: a flash flood case study in the Western Mediterranean. Nat. 866 Hazards Earth Syst. Sci. 5: 603-612. 
869

\begin{tabular}{|c|c|c|c|}
\hline $\begin{array}{l}\text { Event name } \\
\text { (Acronym) } \\
\text { Type of event } \\
\end{array}$ & $\begin{array}{l}\text { Initial Condition for } \\
\text { BOLAM }\end{array}$ & $\begin{array}{l}\text { Initial Condition for } \\
\text { MOLOCH }\end{array}$ & $\begin{array}{l}\text { Max Rainfall } \\
\text { Observation (Simulation) } \\
\text { Accumulation period }\end{array}$ \\
\hline $\begin{array}{l}\text { HyMeX - IOP19 } \\
\text { (IOP19) } \\
\text { Alpine }\end{array}$ & $\begin{array}{l}04 \text { November } 2012 \\
00 \text { UTC }\end{array}$ & $\begin{array}{l}04 \text { November } 2012 \\
03 \text { UTC }\end{array}$ & $\begin{array}{l}370(350) \mathrm{mm} / 30 \mathrm{~h} \\
04 \mathrm{Nov}, 06 \mathrm{UTC}- \\
05 \text { Nov. } 12 \text { UTC }\end{array}$ \\
\hline $\begin{array}{l}\text { Piancavallo } 2012 \\
\text { (P2012) } \\
\text { Alpine }\end{array}$ & $\begin{array}{l}10 \text { November } 2012 \\
12 \text { UTC }\end{array}$ & $\begin{array}{l}10 \text { November } 2012 \\
15 \text { UTC }\end{array}$ & $\begin{array}{l}390(310) \mathrm{mm} / 24 \mathrm{~h} \\
11 \mathrm{Nov}, 00 \mathrm{UTC}- \\
12 \mathrm{Nov}, 00 \mathrm{UTC}\end{array}$ \\
\hline $\begin{array}{l}\text { Vicenza } 2010 \\
\text { (V2010) } \\
\text { Alpine }\end{array}$ & $\begin{array}{l}30 \text { October } 2010 \\
18 \text { UTC }\end{array}$ & $\begin{array}{l}30 \text { October } 2010 \\
21 \text { UTC }\end{array}$ & $\begin{array}{l}600(600) \mathrm{mm} / 48 \mathrm{~h} \\
31 \text { Oct, 00 UTC - } \\
02 \text { Nov, 00 UTC }\end{array}$ \\
\hline $\begin{array}{l}\text { HyMeX - IOP18 } \\
\text { (IOP18) } \\
\text { Upstream } \\
\end{array}$ & $\begin{array}{l}31 \text { October } 2012 \\
00 \text { UTC }\end{array}$ & $\begin{array}{l}31 \text { October } 2012 \\
06 \text { UTC }\end{array}$ & $\begin{array}{l}120(140) \mathrm{mm} / 24 \mathrm{~h} \\
31 \text { Oct, } 12 \mathrm{UTC}- \\
01 \text { Nov, } 12 \text { UTC }\end{array}$ \\
\hline $\begin{array}{l}\text { Marghera } 2007 \\
\text { (M2007) } \\
\text { Upstream }\end{array}$ & $\begin{array}{l}25 \text { September } 2007 \\
12 \text { UTC }\end{array}$ & $\begin{array}{l}25 \text { September } 2007 \\
18 \text { UTC }\end{array}$ & $\begin{array}{l}320(330) \mathrm{mm} / 12 \mathrm{~h} \\
26 \text { Sep. 00 UTC - } \\
26 \text { Sep. } 12 \text { UTC }\end{array}$ \\
\hline $\begin{array}{l}\text { Mira 2009 } \\
\text { (M2009) } \\
\text { Upstream }\end{array}$ & $\begin{array}{l}15 \text { September } 2009 \\
18 \text { UTC }\end{array}$ & $\begin{array}{l}16 \text { September } 2009 \\
00 \text { UTC }\end{array}$ & $\begin{array}{l}180(210) \mathrm{mm} / 24 \mathrm{~h} \\
16 \mathrm{Sep} 00 \mathrm{UTC}- \\
17 \mathrm{Sep} 00 \mathrm{UTC}\end{array}$ \\
\hline
\end{tabular}

870

871 Table 1: List of analysed events and their acronyms, initialization time for BOLAM and MOLOCH

872 simulations, accumulated (observed and forecast) precipitation and selected rainfall accumulation 873 period.

874

875 


\begin{tabular}{|l|l|l|l|l|l|l|}
\hline $\begin{array}{l}\text { Alpine } \\
\text { event }\end{array}$ & Analysed time & $\begin{array}{l}\text { Initiation of } \\
\text { intense } \\
\text { precipitation }\end{array}$ & $\begin{array}{l}\text { CAPE } \\
\left(\mathrm{J} \mathrm{kg}^{-1}\right)\end{array}$ & $\begin{array}{l}\text { Lifted } \\
\text { Index } \\
(\mathrm{K})\end{array}$ & $\begin{array}{l}\mathrm{h}_{\mathrm{b}} \\
(\mathrm{m})\end{array}$ & $\begin{array}{l}\mathrm{U} \\
\left(\mathrm{m} \mathrm{s}^{-1}\right)\end{array}$ \\
\hline IOP19 & $\begin{array}{l}\text { 04 Nov 2012 } 2012 \\
15 \text { UTC }\end{array}$ & 100 & 2.2 & 480 & 13.2 \\
\hline P2012 & $\begin{array}{l}\text { 10 Nov 2012 } \\
\text { 18 UTC }\end{array}$ & $\begin{array}{l}\text { 11 Nov 2012 } \\
\text { 00 UTC }\end{array}$ & 3 & 4.6 & 500 & 12.3 \\
\hline V2010 & $\begin{array}{l}\text { 31 Oct 2010 } \\
\text { 03 UTC }\end{array}$ & $\begin{array}{l}\text { 31 Oct 2010 } \\
\text { 06 UTC }\end{array}$ & 40 & 4.3 & 480 & 12.1 \\
\hline
\end{tabular}

877

878 Table 2: Summary of parameters computed for the triggering phase for the three Alpine events.

879 Convective Available Potential Energy (CAPE), Lifted Index (LI), depth of the stable layer

880 characterised by barrier wind over the NEI plain $\left(h_{b}\right)$, meridional component of the wind averaged

881 among the model levels below $2000 \mathrm{~m}(\mathrm{U})$. The most unstable parcel was used in the computation. 


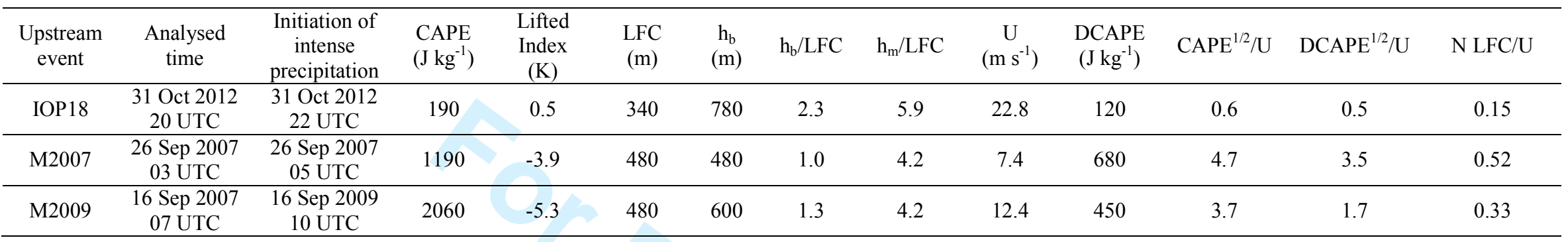

Table 3: Summary of parameters computed for the triggering phase for the three Upstream events. Convective Available Potential Energy (CAPE), Lifted Index (LI), depth of the stable layer characterised by barrier wind over the NEI plain $\left(\mathrm{h}_{\mathrm{b}}\right)$, ratio between $\mathrm{h}_{\mathrm{b}}$ and LFC, ratio between ridge height $\left(\mathrm{h}_{\mathrm{m}}=2000 \mathrm{~m}\right)$ and LFC, meridional component of the wind averaged among the model levels below $2000 \mathrm{~m}$ (U), Downdraft Convective Available Potential Energy (DCAPE), CAPE ${ }^{1 / 2} / \mathrm{U}, \mathrm{DCAPE}^{1 / 2} / \mathrm{U}, \mathrm{N}$ LFC / U. The most unstable parcel was used in the computation. 
892

893

894

895 Figure 1: area of interest corresponding to the MOLOCH integration domain and indication of the 896 locations mentioned in the text: Venice (cross), Vicenza (plus), Padua (star), Concordia Sagittaria 897 (dot) SODAR and Campoformido (Udine) sounding (triangle). The NEI area including the Friuli 898 Venezia Giulia (FVG) and Veneto regions is also indicated. Model orography above 1500 meters is 899 shaded.

900

901 Figure 2: synoptic situation for the six events (IFS - ECMWF analyses). Geopotential height at 500 $902 \mathrm{hPa}\left(\right.$ dam, black lines), sea level pressure $\left(\mathrm{hPa}\right.$, white lines) and temperature at $500 \mathrm{hPa}\left({ }^{\circ} \mathrm{C}\right.$, colour 903 shading). (a) IOP19, 05 Nov. 2012 at 0600 UTC; (b) Piancavallo event, 11 Nov. 2012 at 0600 UTC; 904 (c) Vicenza event, 01 Nov. 2010 at 0000 UTC; (d) IOP18, 31 Oct. 2012 at 1200 UTC; (e) Marghera 905 event, 26 Sep. 2007 at 0600 UTC; (f) Mira event, 16 Sep. 2009 at 1200 UTC.

906

907 Figure 3: observed precipitation, obtained by interpolation of data provided by the dense networks 908 of Veneto (about 170 rain-gauges) and FVG (about 260 rain-gauges) regional meteorological 909 agencies, for the six events. (a) IOP19, 30-h accumulated precipitation at 1200 UTC, 05 Nov. 2012; 910 (b) Piancavallo event, 24-h accumulated precipitation at 0000 UTC, 12 Nov. 2012; (c) Vicenza 911 event, 48-h accumulated precipitation at 0000 UTC, 02 Nov. 2010; (d) IOP18, 24-h accumulated 912 precipitation at 1200 UTC, 01 Nov. 2012; (e) Marghera event, 12-h accumulated precipitation at 9131200 UTC, 26 Sep. 2007; (f) Mira event, 24-h accumulated precipitation at 0000 UTC, 17 Sep. 914 2009. The regional border of Veneto and FVG regions are also plotted.

915

916 Figure 4: as in Fig. 3, but for MOLOCH forecasts. 
918 Figure 5: (a) High-resolution SODAR wind data in Concordia Sagittaria between 0300 and 1200

919 UTC, 31 Oct. 2010 (V2010 event). (b) High-resolution SODAR wind data in Padua between 0000 920 and 1200 UTC, 26 Sep. 2007 (M2007 event). Note that the time reported on the x-axis are in CET, 921 corresponding to UTC+1.

922

923 Figure 6: evolution of the Froude number for the six heavy-precipitation events over the Alps, 924 Hours on $\mathrm{x}$-axis are referred to the initiation of intense precipitation. Dashed (solid) lines for the 925 Upstream (Alpine) events.

926

927 Figure 7: MOLOCH 10-meter wind ( $\mathrm{m} \mathrm{s}^{-1}$, shading) during the initial stage of the events, when the 928 Sirocco wind is blocked by the orography and deflected as barrier wind ahead of the Alps: (a) 929 Vicenza event, 31 Oct. 2010, 0300 UTC; (b) Marghera event, 26 Sep. 2007, 0400 UTC. The black 930 dashed lines indicate the location of the vertical cross-sections shown in Fig. 8. The black square 931 indicates the area where averaged vertical profiles are computed. During the precipitation stage of 932 the events: (c) flow-over condition for the Vicenza event, 31 Oct. 2010, 1800 UTC; (d) persisting 933 blocked-flow condition for the Marghera event, 26 Sep. 2007, 1200 UTC. Note that only a portion 934 of the MOLOCH integration domain is shown. Black contours show the $500 \mathrm{~m}$ and $1500 \mathrm{~m}$ 935 orography elevation.

936

937 Figure 8: MOLOCH vertical cross-sections along the black line indicated in Fig. 7. Equivalent 938 potential temperature (thin contour line and colour shading, interval $2 \mathrm{~K}$ ), tangent wind component 939 (vectors) and cloud water and ice (thick contour indicating $0.1 \mathrm{~g} \mathrm{~kg}^{-1}$ ), for Vicenza event (cross 940 section length $314 \mathrm{~km}$ ), (a) 31 Oct. 2010, 0300 UTC and (c) 01 Nov. 2010, 1000 UTC; Marghera 941 event (cross section length $363 \mathrm{~km}$ ), 26 Sep. 2007, (b) at 0400 UTC and (d) at1200 UTC. 942 
943 Figure 9: vertical thermodynamic profiles simulated by MOLOCH during the initial stage of the

944 events and computed as an average over an area of about 15 x $15 \mathrm{~km}$ for (a) Vicenza event, 31 Oct.

$9452010,0300 \mathrm{UTC}$, in $45.1^{\circ} \mathrm{N}, 12.9^{\circ} \mathrm{E}$; (b) Marghera event, 26 Sep. 2007, $0400 \mathrm{UTC}$, in $45^{\circ} \mathrm{N}, 13$

$946{ }^{\circ} \mathrm{E}$.

947

948 Figure 10: profiles of buoyancy for air parcels raised to a height of $500 \mathrm{~m}$ above their initial

949 position (vertical axis). Profiles are computed for the initial stage of the events, before intense 950 precipitation occurrence. Dashed (solid) lines for the Upstream (Alpine) events. Values on the x951 axis are multiplied by $10^{2}$.

952

953 Figure 11: evolution of $h_{m} /$ LFC for the three Alpine events. Hours on $\mathrm{x}$-axis are referred to the 954 initiation of intense precipitation.

955

956 Figure 12: results of MOLOCH simulations performed removing the contribution of 957 evaporation/sublimation of the precipitation (see text). Marghera event (cross section length 363 $958 \mathrm{~km}$ ): (a) 12-h accumulated precipitation at 1200 UTC, 26 Sep. 2007; (b) vertical cross-sections 959 along the black line of Fig. 7 showing equivalent potential temperature (thin contour line and colour 960 shading, interval $2 \mathrm{~K}$ ), tangent wind component (vectors) and cloud water and ice (thick contour 961 indicating $0.1 \mathrm{~g} \mathrm{~kg}^{-1}$ ) on 26 Sep. 2007 at 1200 UTC.

962

963 Figure 13: schematic diagram of the key mechanisms responsible for the two different precipitation 964 patterns over NEI. (a) Upstream event: blocked low-level flow, barrier wind, convergence and deep 965 convection development occurring over the plain, upstream of the orography. (b) Alpine event: 966 unblocked low-level flow, flow-over conditions, orographic lifting and precipitation over the Alps 967 with possible embedded convection. 


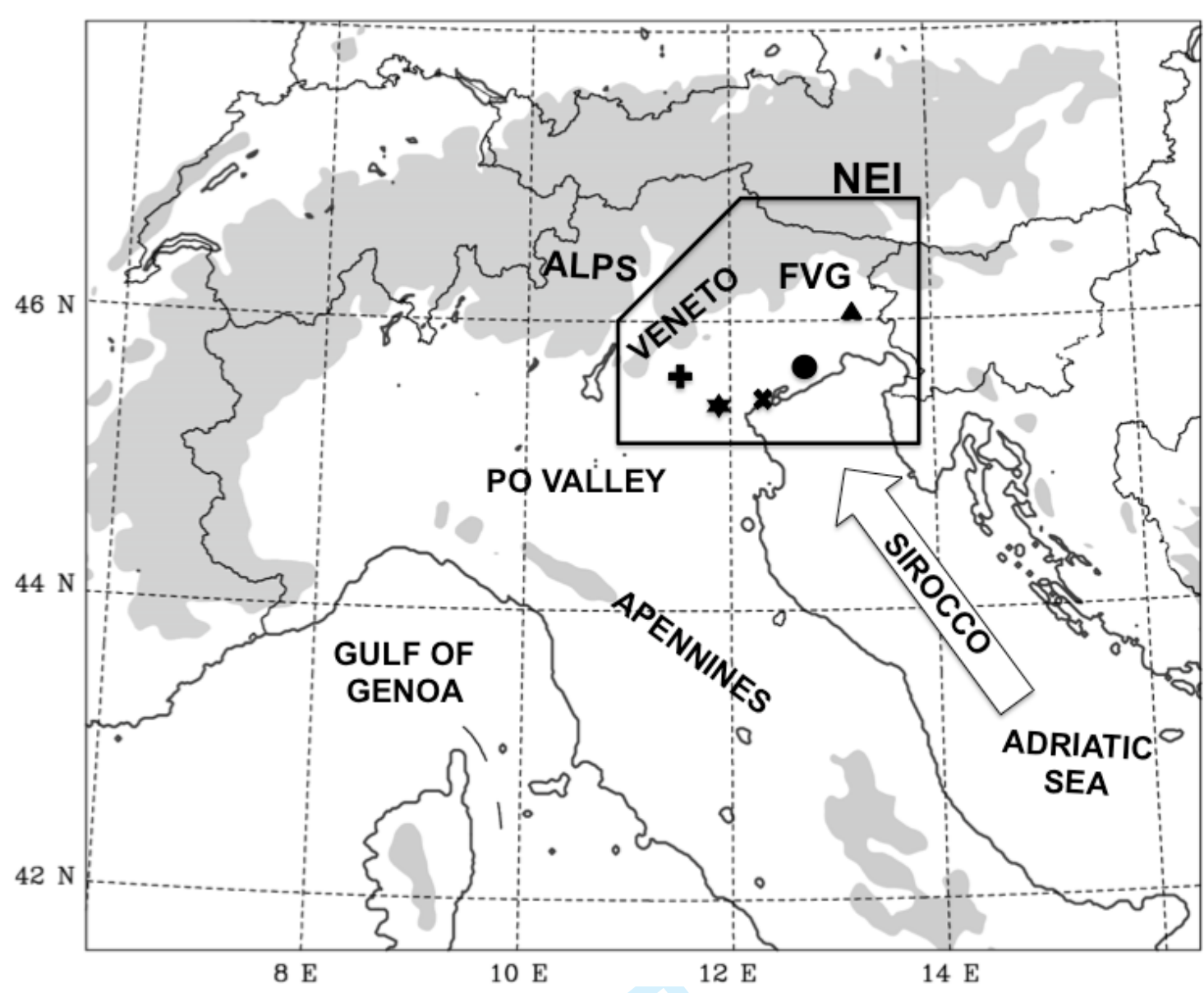

969

970

$971 \quad$ Figure 1

972 

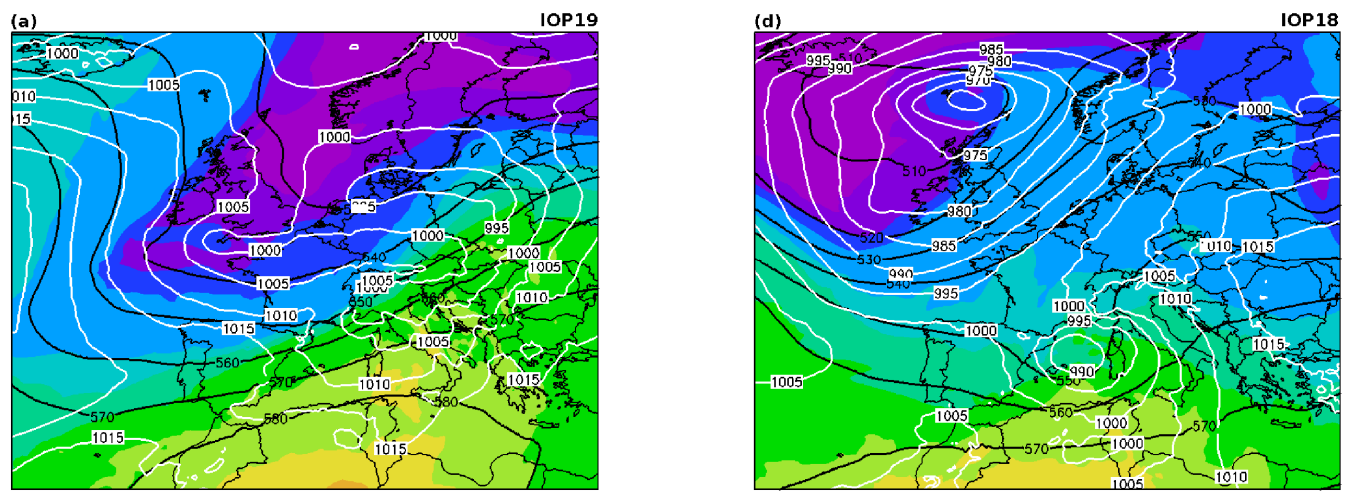

973
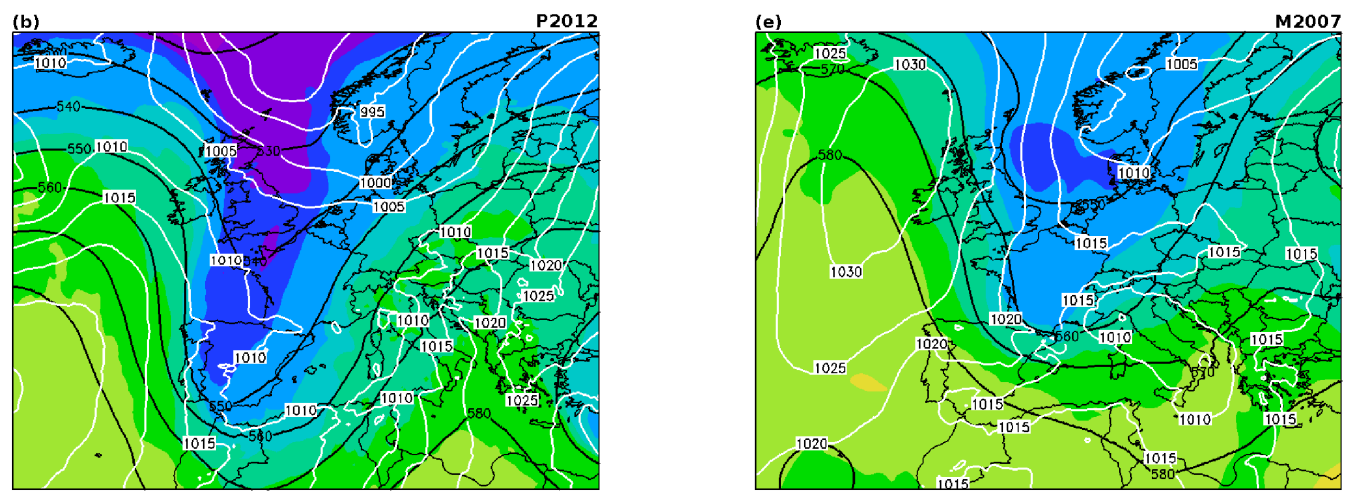

974
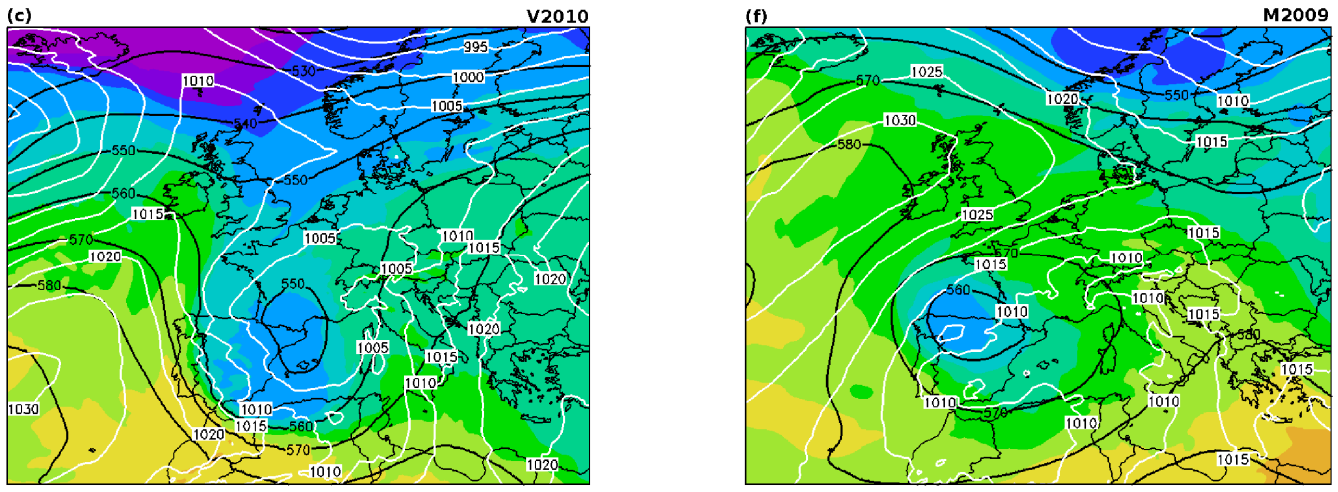

975

976

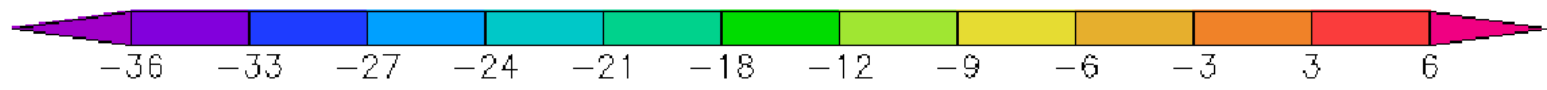

$977 \quad$ Figure 2

978 

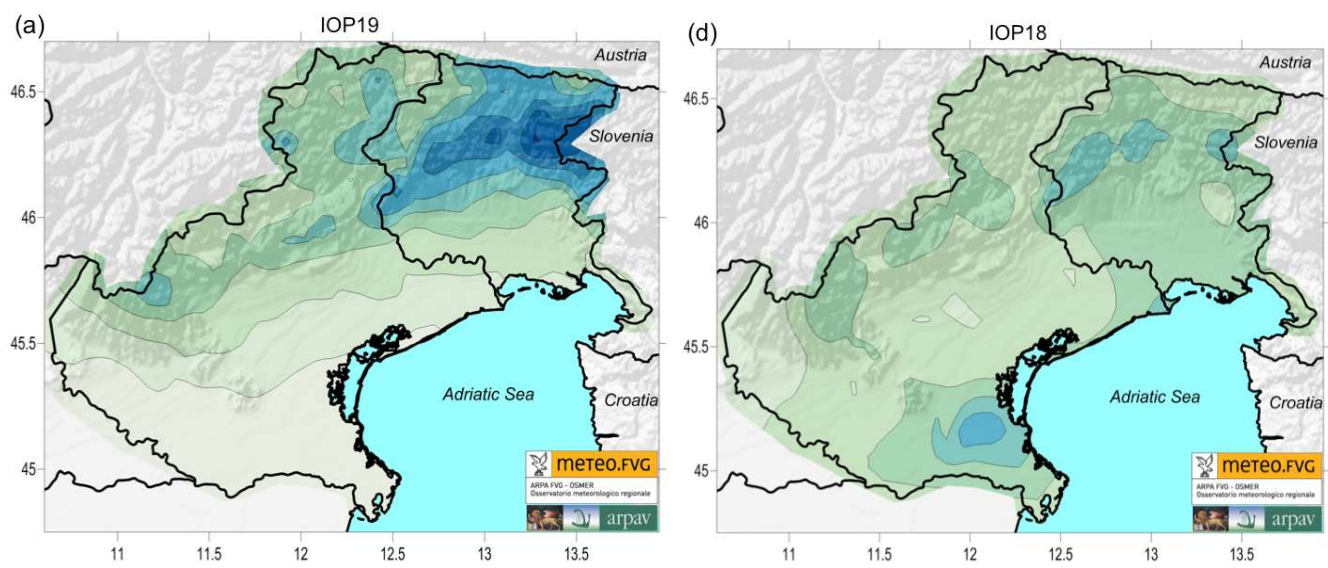

980
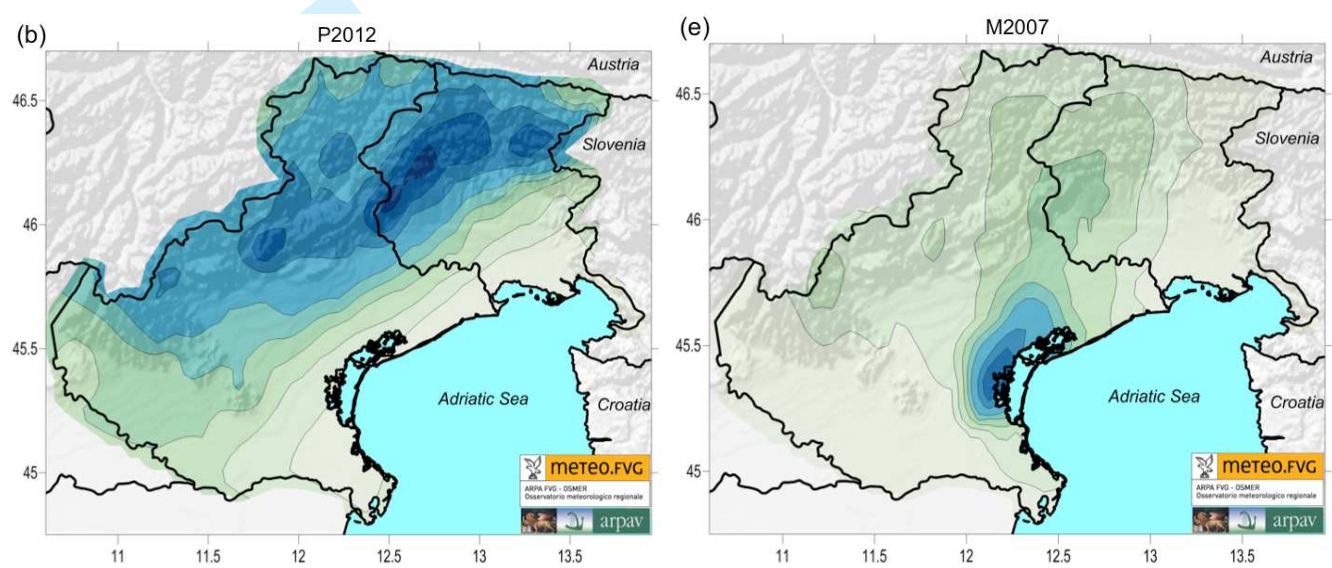

981

\section{(19)}

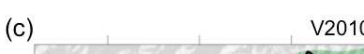

982
2010

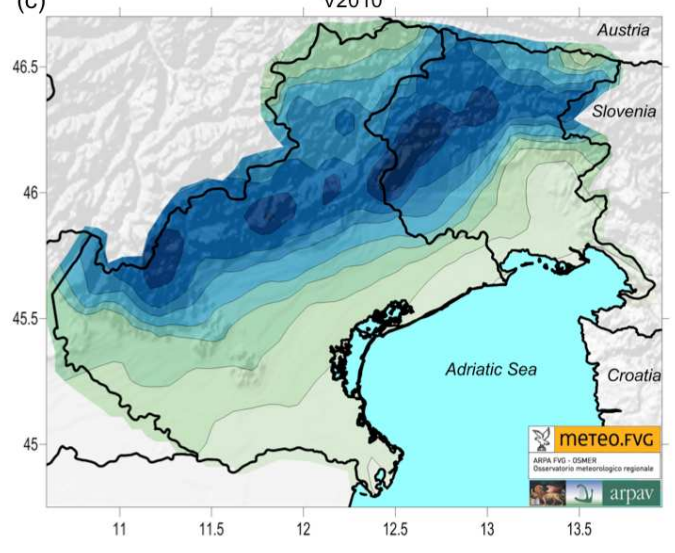

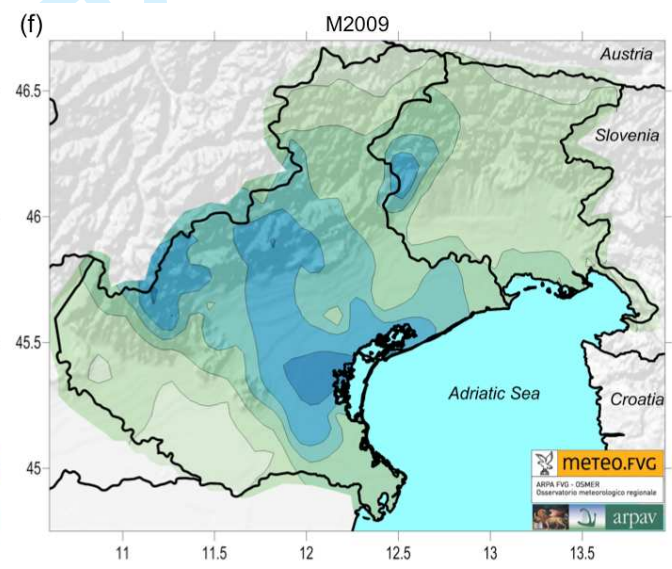

983 Figure 3

984 

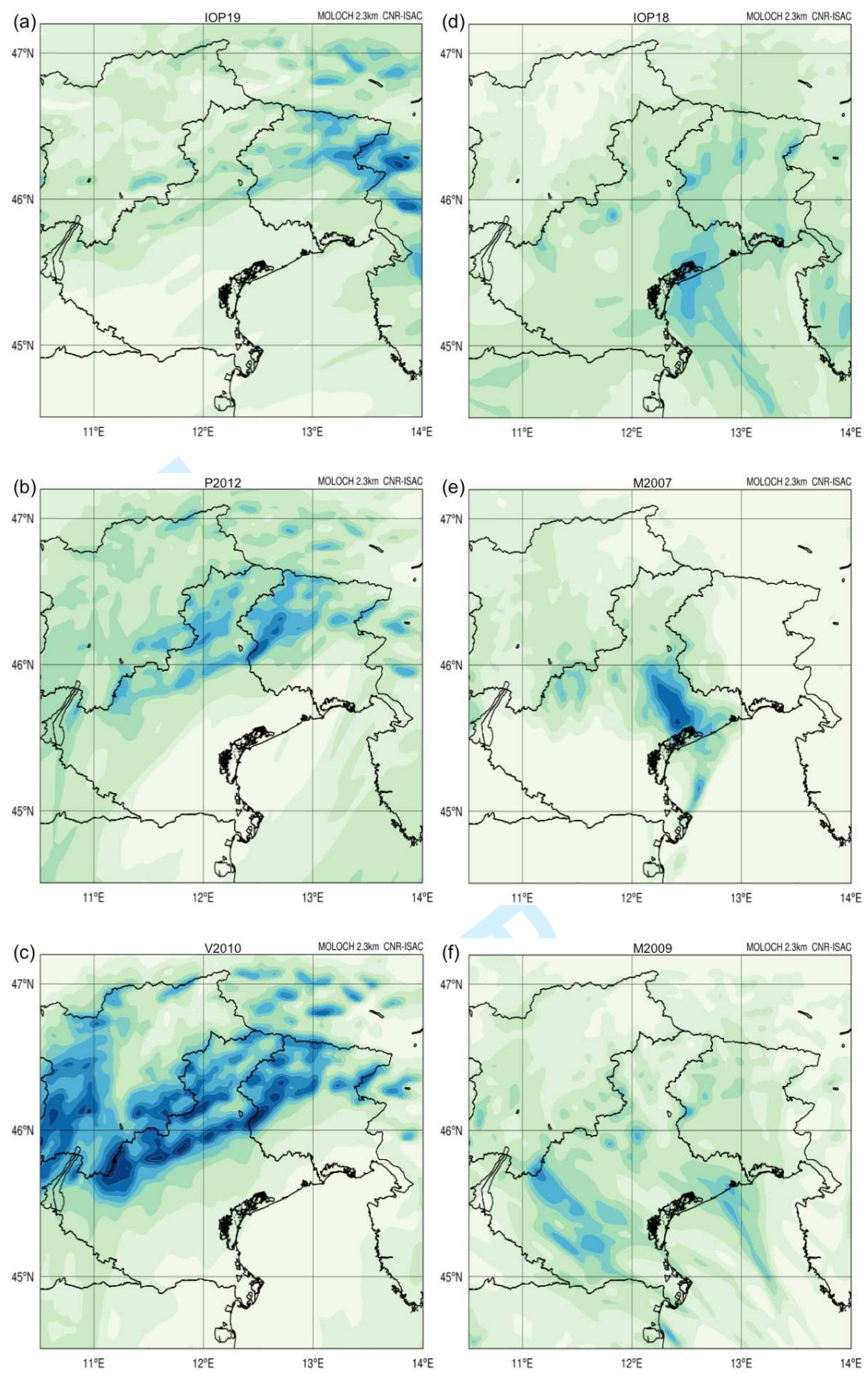

988

$\begin{array}{llllllllll}0 & 10 & 25 & 50 & 75 & 100 & 150 & 200 & 300 & 400\end{array}$

989 Figure 4 
1

2

3

4

5

6

7

8

9

10

11

12

13

14

15

16

17

18

19

20

21

22

23

24

25

26

27

28

29

30

31

32

33

34

35

36

37

38

39

40

41

42

43

44

45

46

47

48

49

50

51

52

53

54

55

56

57

58

59

60
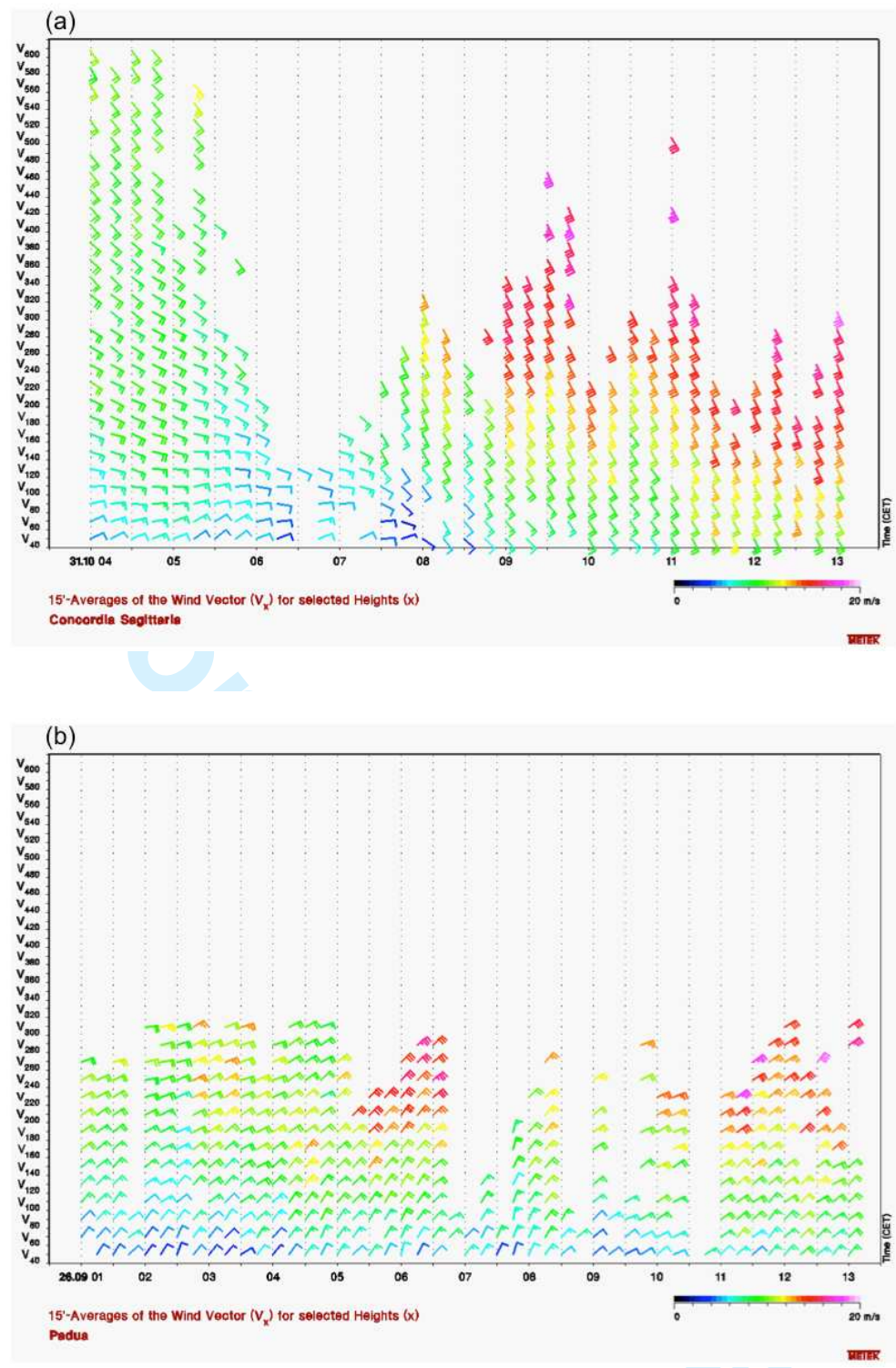

993 Figure 5

994 


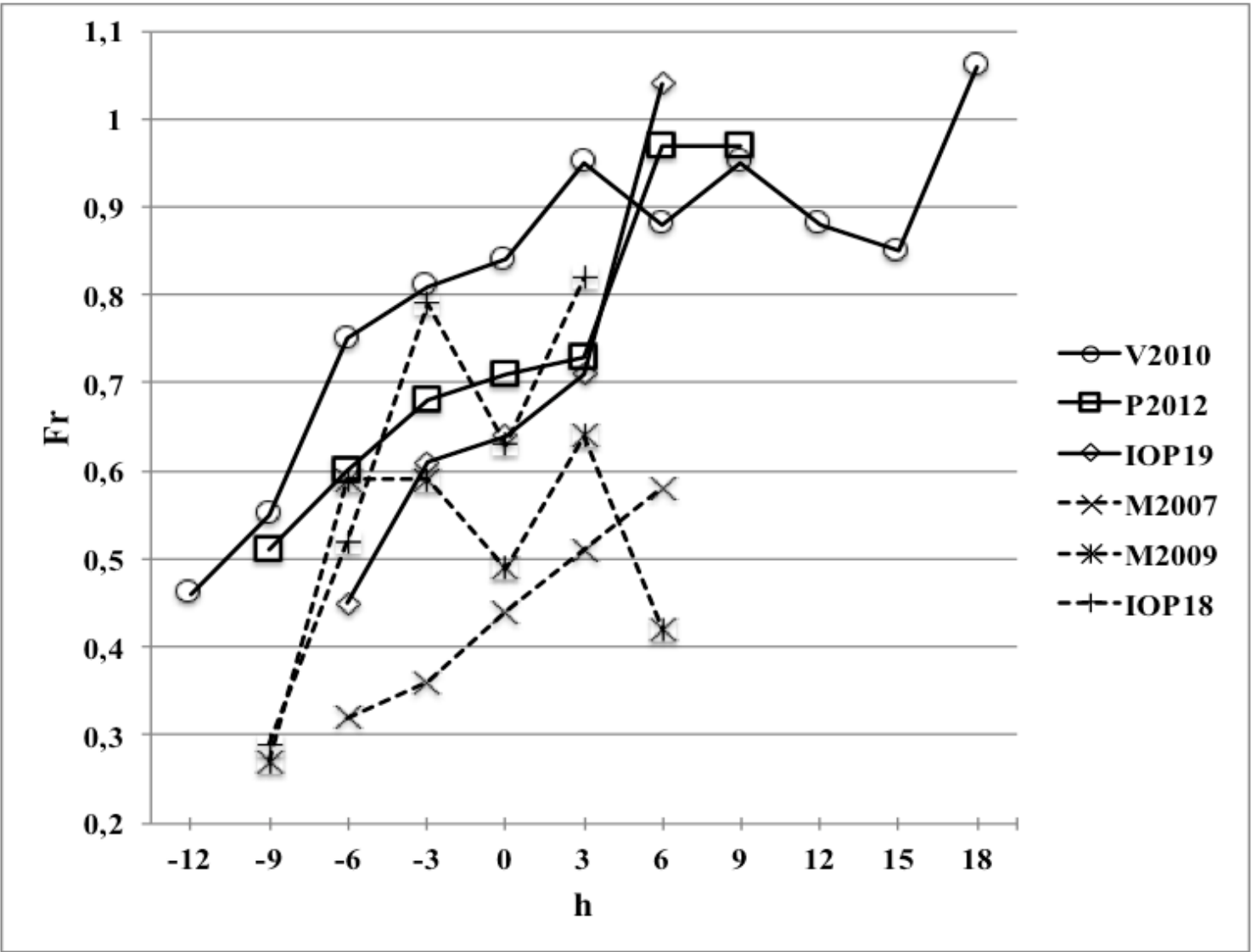

995

996 Figure 6

997 
(a)

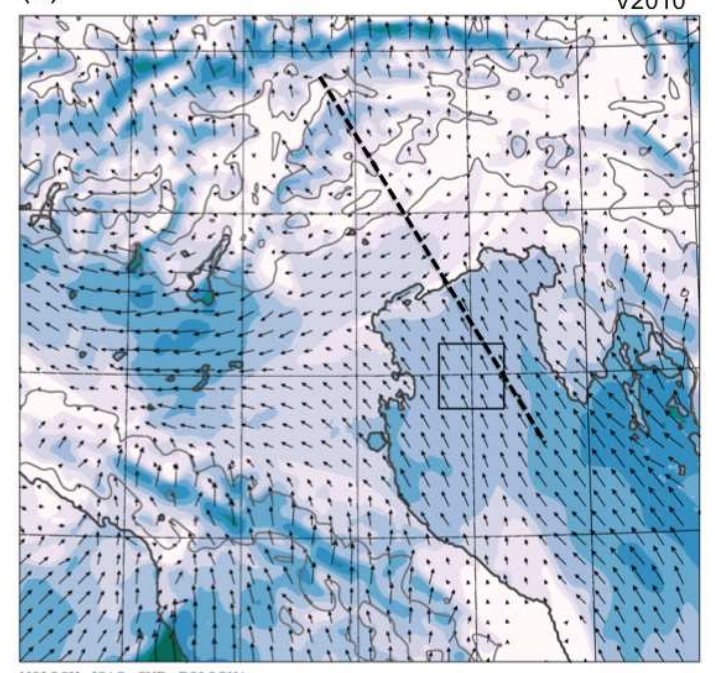

(c)

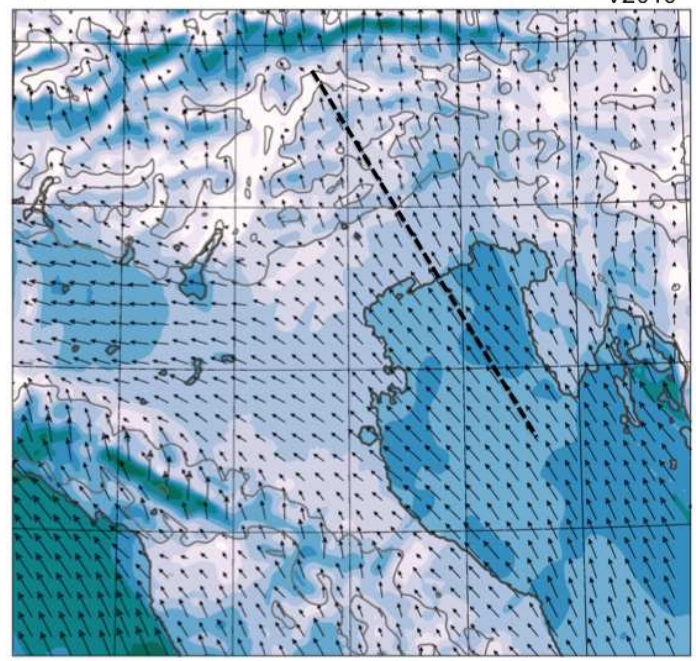

(b)

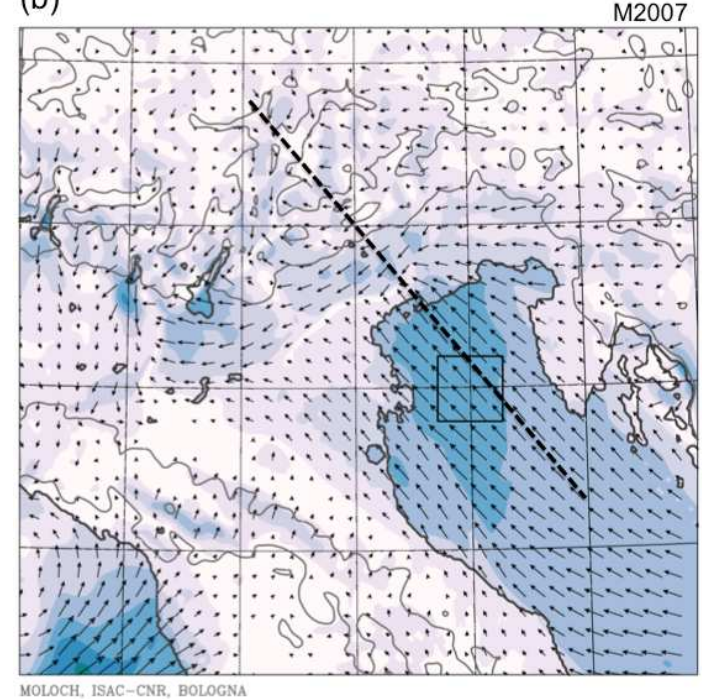

(d)

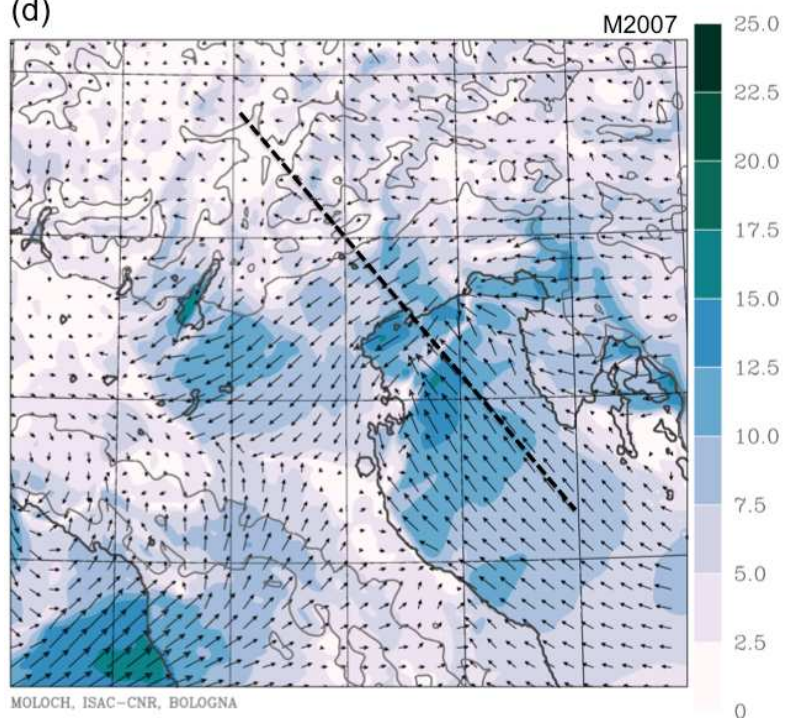

$1000 \quad$ Figure 7

1001 
(a) V2010 (c)

(c)
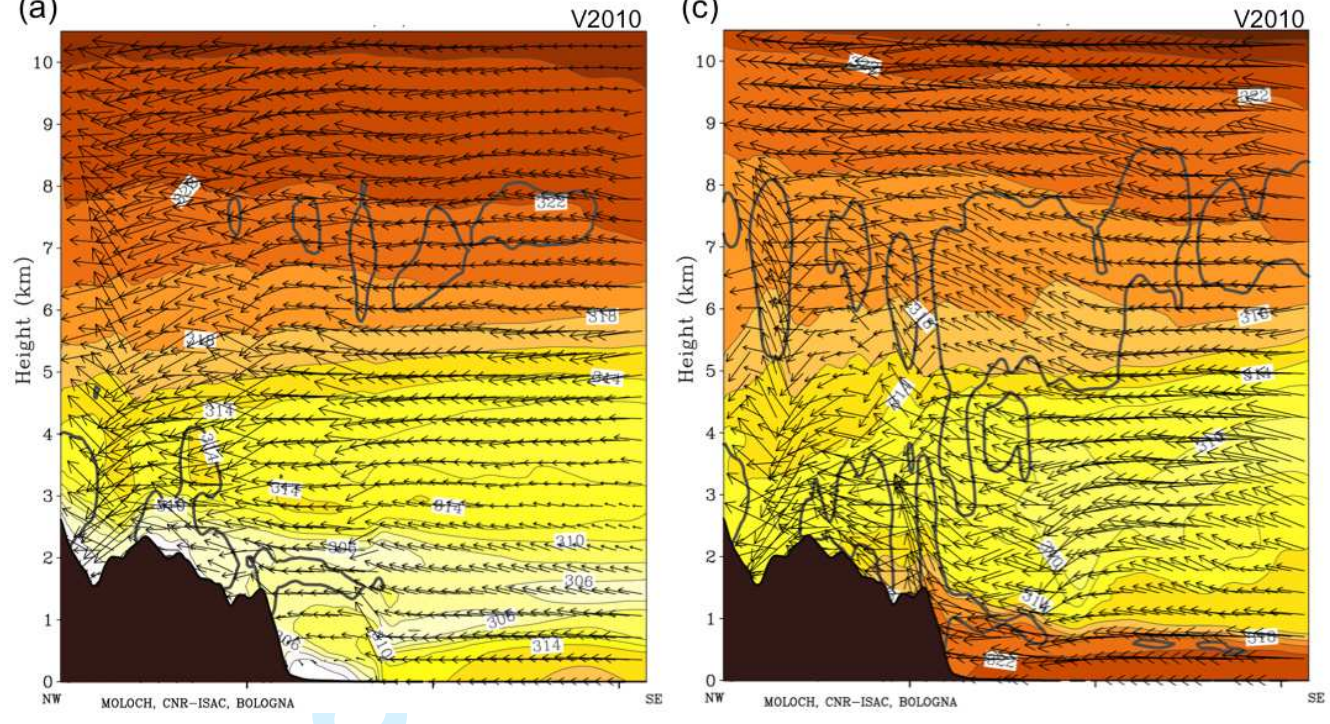

(b)

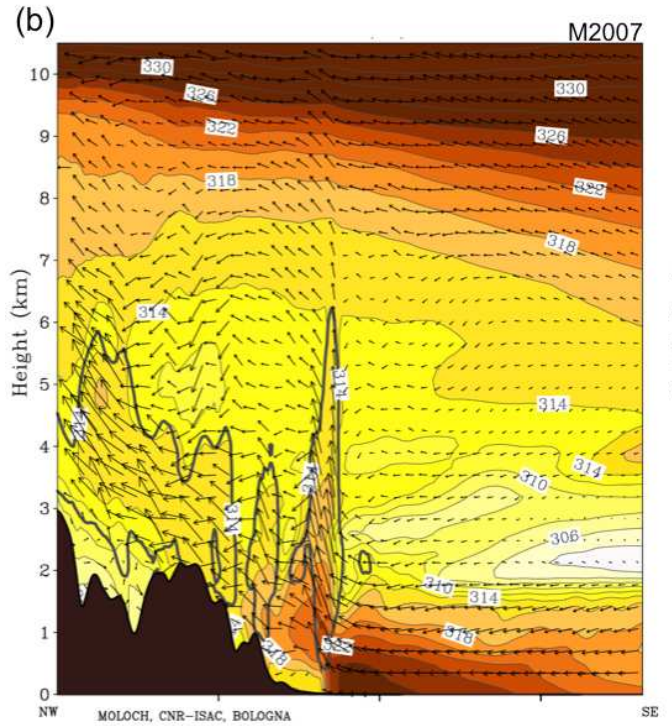

(d)

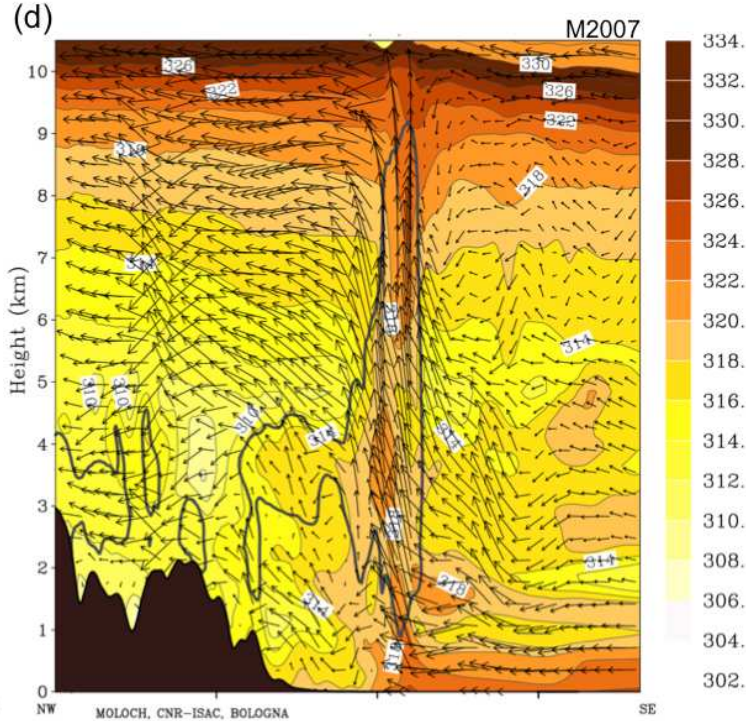

1004 Figure 8

1005 
1

2

3

4

5

6

7

8

9

10

11

12

13

14

15

16

17

18

19

20

21

22

23

24

25

26

27

28

29

30

31

32

33

34

35

36

37

38

39

40

41

42

43

44

45

46

47

48

49

50

51

52

53

54

55

56

57

58

59

60
1006
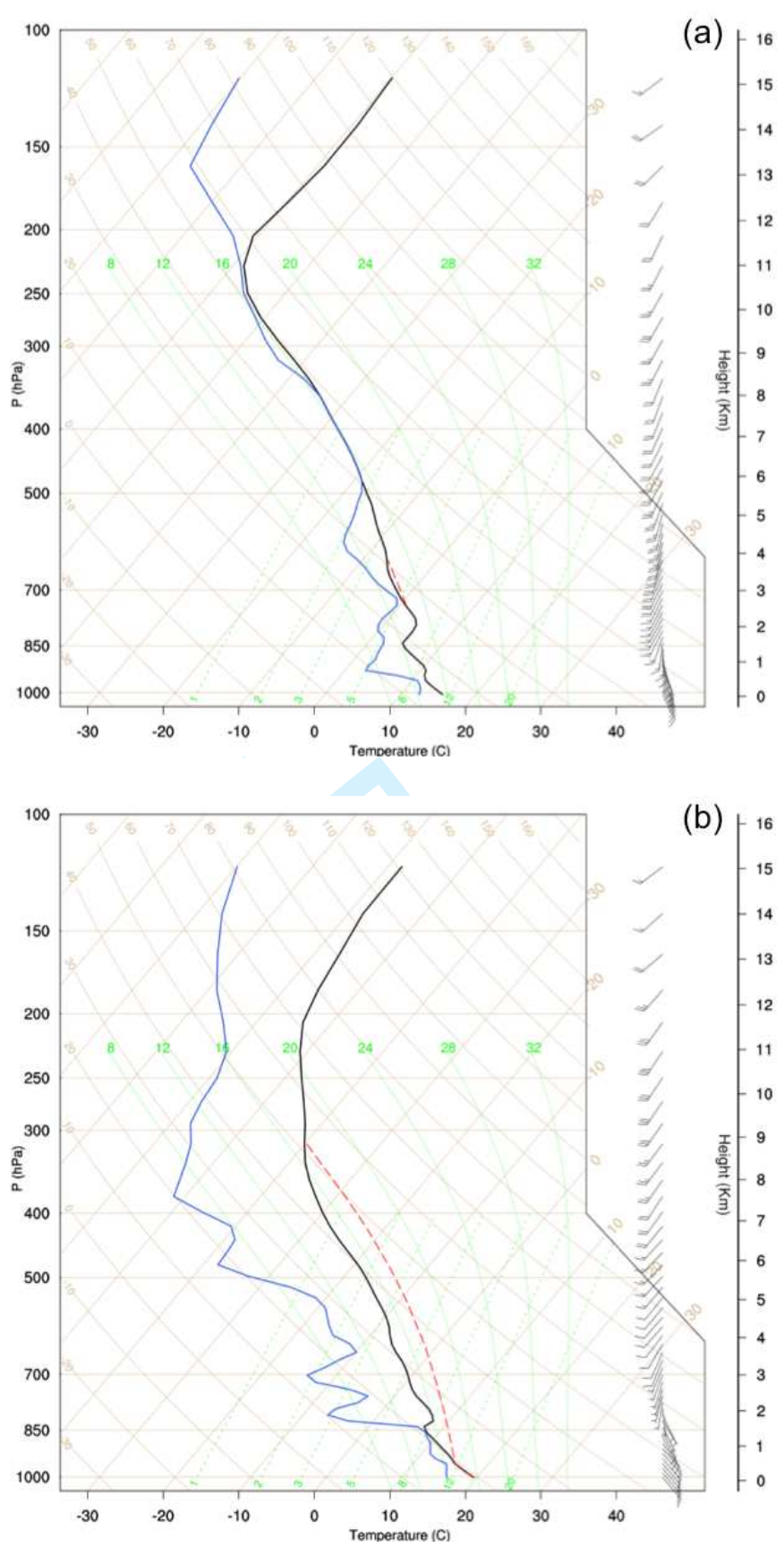

1007

1008 Figure 9

1009 


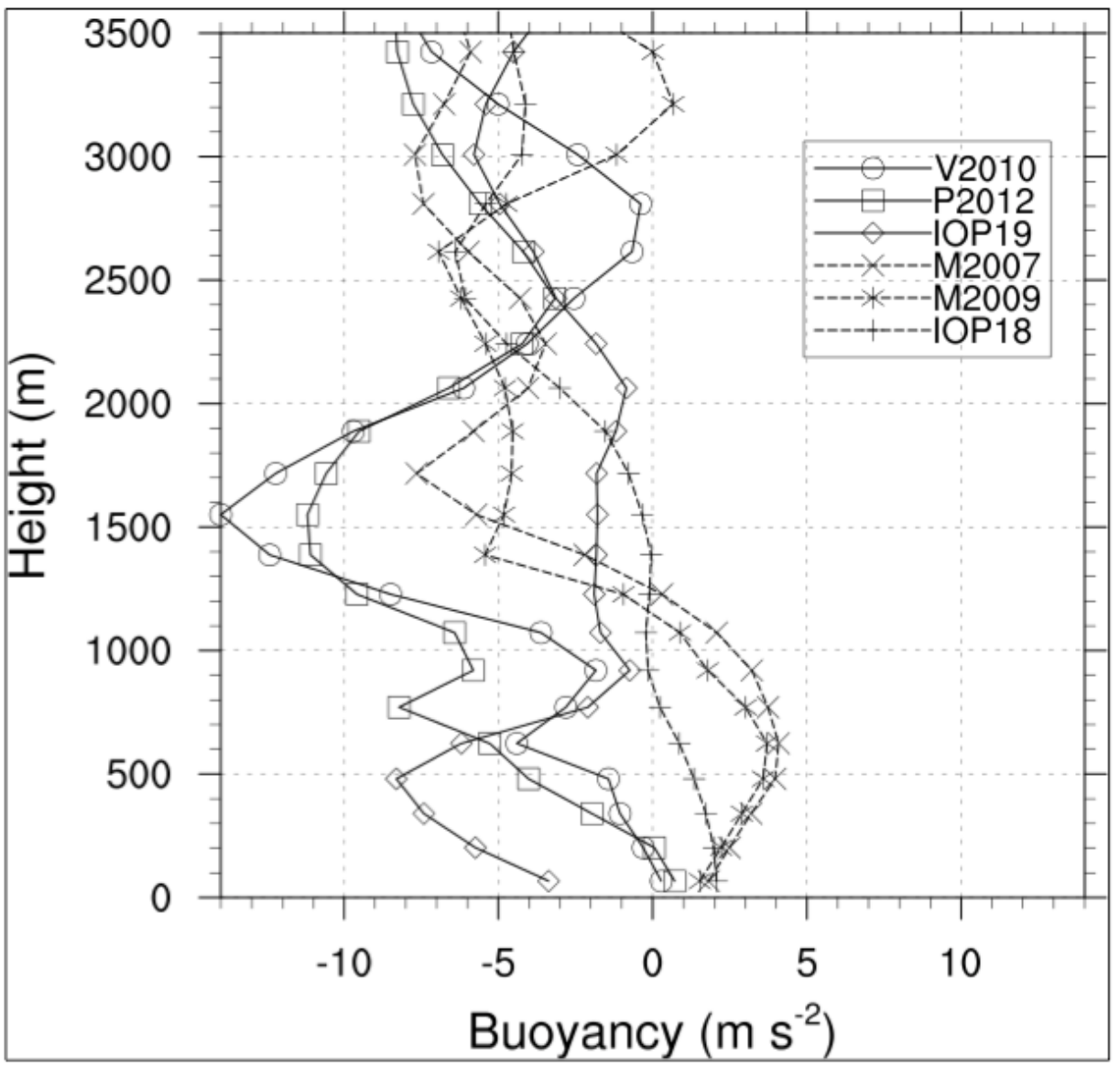

1010

Figure 10

1012 


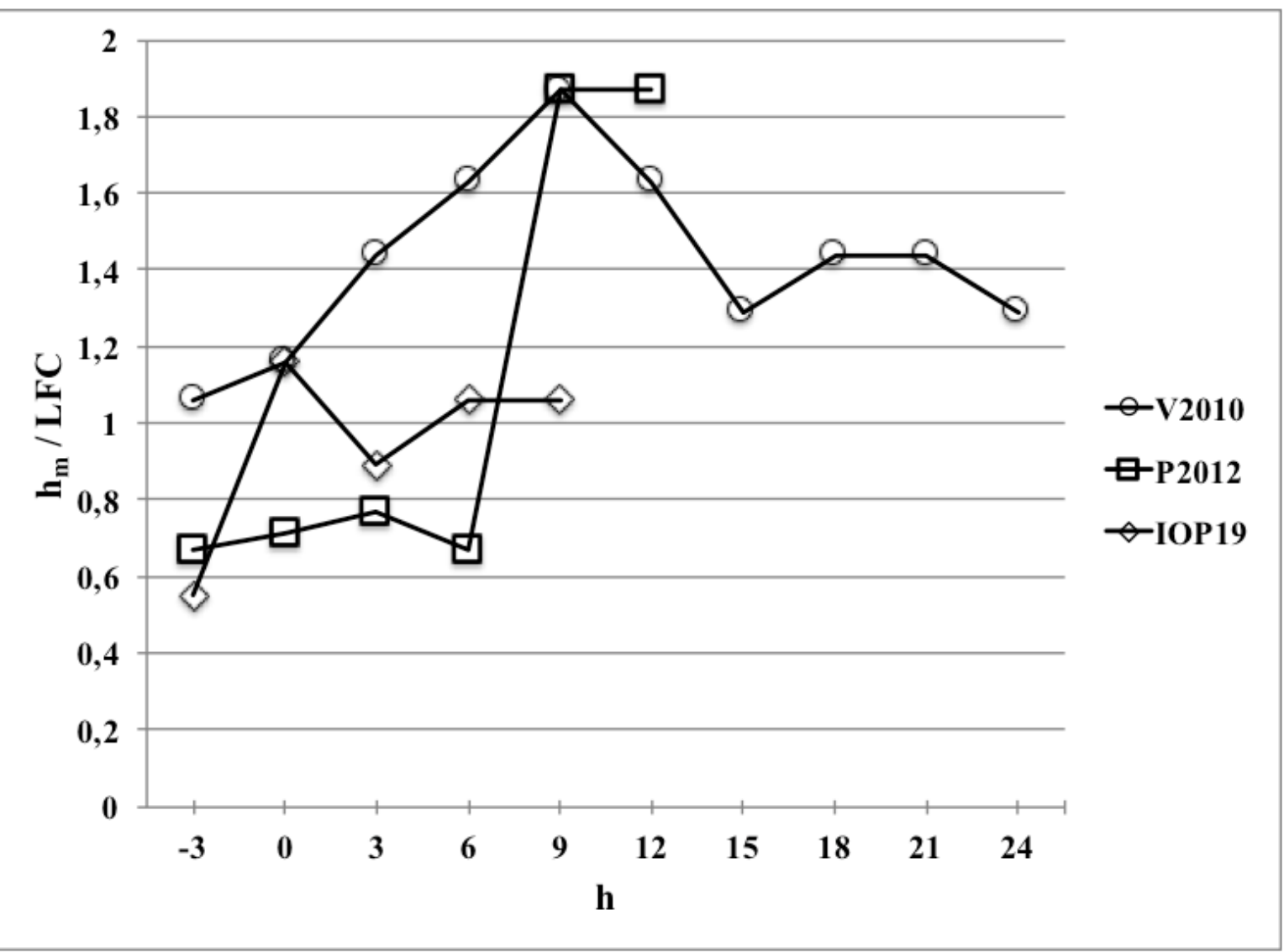

$1014 \quad$ Figure 11

1015 

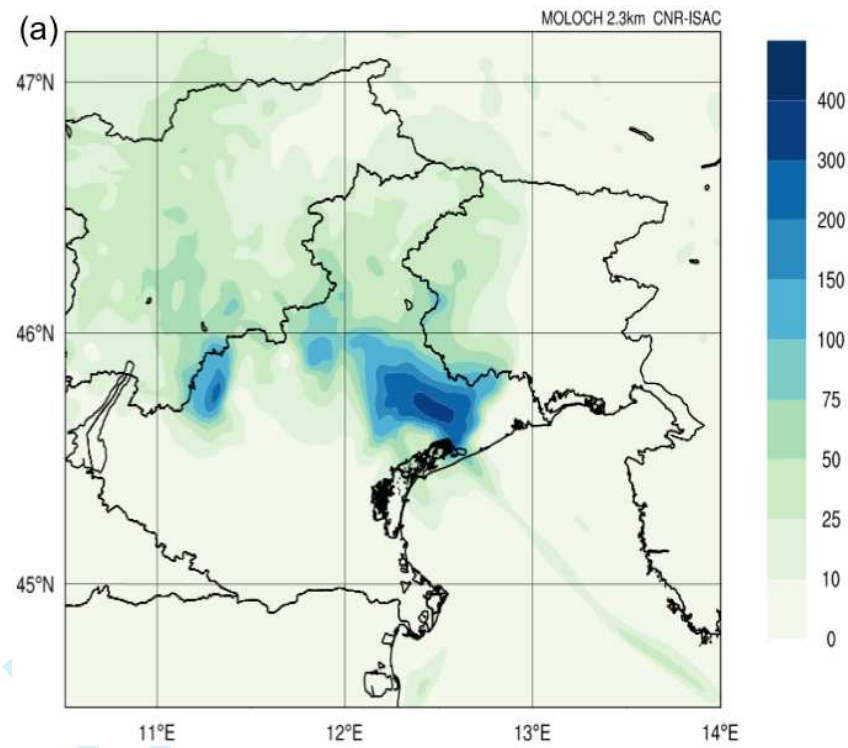

(b)

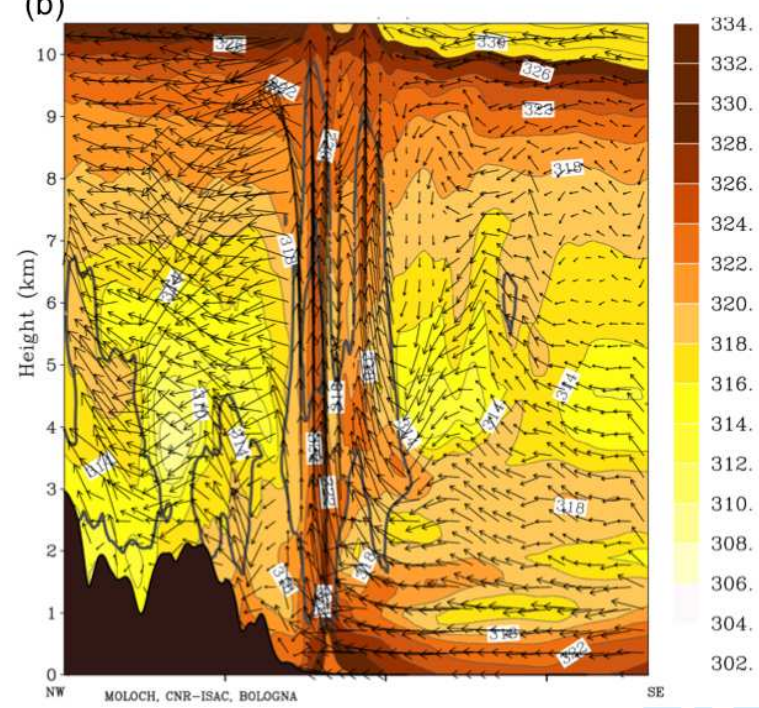

1018 Figure 12 
(a)

(b)

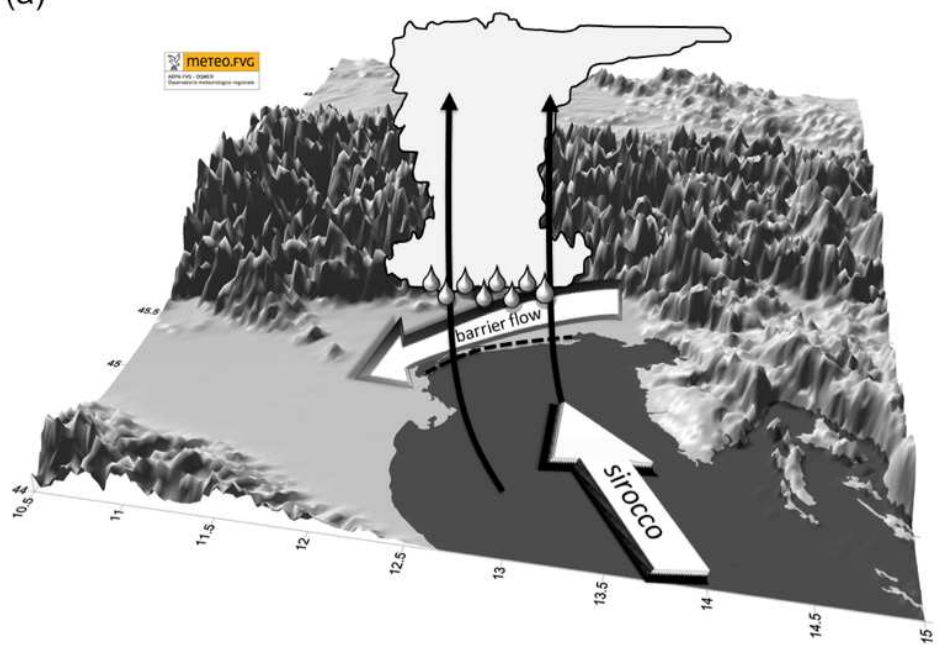

1022 Figure 13

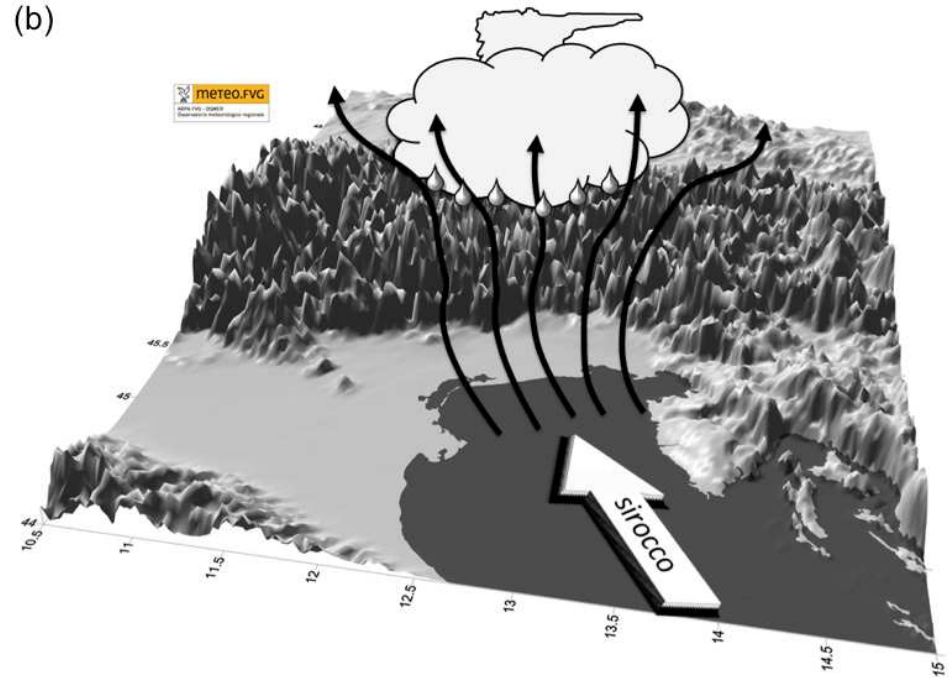

